\title{
Securitization and business cycle: an agent-based perspective
}

\section{Andrea Mazzocchetti, ${ }^{1, *}$ Marco Raberto, ${ }^{2}$ Andrea Teglio ${ }^{3,4}$ and Silvano Cincotti ${ }^{5}$}

${ }^{1}$ DIME-CINEF Università di Genova, Via Opera Pia 15, Genova, 16145, Italy. e-mail: andrea.mazzocchetti@edu.unige.it, ${ }^{2}$ DIME-CINEF Università di Genova, Via Opera Pia 15, Genova, 16145, Italy. e-mail: marco.raberto@unige.it, ${ }^{3}$ Department of Economics, University Ca' Foscari of Venice, Cannaregio 873, Venezia, 30121, Italy. e-mail: andrea.teglio@unive.it, ${ }^{4}$ Campus del Riu Sec, Universitat Jaume I, Castellon, 12071, Spain. e-mail: andrea.teglio@unive.it and ${ }^{5}$ DIME-CINEF Università di Genova, Via Opera Pia 15, Genova, 10 16145, Italy. e-mail: silvano.cincotti@unige.it

*Main author for correspondence.

\section{Abstract}

We study the effects of loans and mortgages securitization on business cycles by using a large-scale agent-based stock-flow consistent macroeconomic model and simulator. We enriched the model by including a financial vehicle corporation, which buys loans and mortgages from banks and issues asset-backed securities (ABSs) and mortgage-backed securities (MBSs), and a mutual fund, which invests both in $\mathrm{ABS}$ s and MBSs using its liquidity resources and issues new shares when in liquidity shortage. Households own the equity of the mutual fund in the form of equity shares. By means of securitization, banks conduct regulatory capital arbitrage and reduce risk-weighted assets in their balance sheet, thus being able to lend more loans and mortgages. Results show that different levels of securitization propensity are able to affect credit and business cycles in different manners. On one side, securitization increases banks' lending activity, influencing positively investment and consumption. On the other side, the increased amount of credit amplifies negative shocks, due to higher loans' write-offs probability $\bar{j}_{\bar{i}}$ triggered by the boosted lending activity. Firms' bankruptcies impact the equity of banks, affecting their ability to grant new loans to consumption goods producers (CGPs), which need credit for their production activity, and mortgages to households, which need them to purchase housing units. The effect of securitization on the economy critically depends on the level of securitization propensity on and the time span considered.

JEL classification: E63, E32, G21, G23

\section{Introduction}

This work studies the impact of securitization on credit and business cycle using a macroeconomic agent-based and stock-flow consistent model. Our aim is to show how securitization process deeply modifies the balance sheet structure of banks with the effect of boosting lending activity, thus increasing consumption and investment, but also making the banking system less resilient to endogenous crises, resulting in more credit rationing that trigger firms 
bankruptcy cascades, worsening economic performance. Increasing the securitization propensity, the second effect prevails on the first one.

Securitization consists in the financial practice of pooling illiquid assets, such as mortgages and loans, and transforming them into tradable securities, i.e., mortgage-backed securities (MBSs) and asset-backed securities (ABSs), more liquid than the underlying loans or receivables, which are sold to interested investors. Securitization allows credit institutions to remove risky assets from their balance sheets and consequently to overcome regulatory capital requirements and increase their source of funding.

In a broader view, securitization can be considered as the core of the so-called shadow banking system, defined by the Financial Stability Board as "the system of credit intermediation that involves entities and activities outside the regular banking system" (FSB, 2011). Shadow banking system includes a multitude of actors and several layers of intermediation. Pozsar et al. (2010) describe in details shadow banks and their relationship with the traditional financial system. Shadow banking system has been listed as one of the main causes of the global financial crisis of 20072009 (Lysandrou and Nesvetailova, 2014; Adrian and Shin, 2010), enhancing the efforts to find more efficient regulatory responses (see Gorton and Metrick, 2010; Nersisyan and Wray, 2010).

Only few studies propose stock-flow consistent models of the shadow banking system or some of its components, focusing on the securitization process and its role in influencing financial and real sectors. Fontana and Godin (2013) study the effects of securitization on bank balance sheet and housing market, showing how securitization process can lead to inflation balloons on security market driven by demand for deposits by speculative households and sales of MBSs in the secondary market. In Bhaduri et al. (2015), authors show how securitization expands credit and derivative trade leading to economic boom, but also increasing the fragility of the banking system, driven by the internal fragility of the finance sector arising from its growing internal scarcity of liquidity. A stock-flow consistent model that includes securitization process is developed also by Nikolaidi (2015), pointing out that the combination of risky financial practices with wage stagnation can increase the likelihood of financial instability in a macro system. Moreover Botta et al. (2016), following a post-Keynesian stock-flow consistent approach (Godley and Lavoie, 2012; Caverzasi and Godin, 2015), provide a model of shadow banking system analyzing its impact on the whole economy from a macroeconomic perspective, showing how banks, before the crisis, were able to increase the issuance of mortgages while apparently keeping their financial position stable; leading to an increase in the financial instability and that securitization process makes legislations on capital requirement not only ineffective but also potentially counterproductive.

We study the functioning and the effects of the securitization mechanism employing an agent-based and stockflow consistent macroeconomic model and simulator. A number of agent-based macro models have been proposed in recent years to address sundry topics, ${ }^{1}$ see Fagiolo and Roventini (2017) for a comprehensive review and comparison of the Dynamic Stochastic General Equilibrium (DSGE) modeling and Agent-Based Modeling (ABM) approaches. We analyze the effects of the securitization across the whole credit cycle and the consequent impact on the business cycle. To the best of our knowledge, this is the first work that includes securitization process in a large-scale agentbased model, characterized by several classes of economic agents that interact through different markets, namely, markets for consumption goods and capital goods, a housing market, a labor market, a credit market, and a financial market for stocks and government bonds.

The main advantage of the agent-based approach is that it allows the study of the emergent aggregate statistical regularities in the economy, which are not originated by the behavior of an "average" individual, but are the result of agents' behavior and interactions. For instance, firms are heterogeneous, among other things, in terms of degree of financial fragility. This type of heterogeneity plays a crucial role in the evolution over time of aggregate variables such as production and unemployment. Moreover, small idiosyncratic shocks at the firm level may generate single firm bankruptcies, which cause credit rationing by banks and so waves of bankruptcies among firms, inducing large aggregate fluctuations in the economy. This process plays a crucial role when we introduce securitization, since banks can

1 A list of macroeconomic ABM includes the $\mathrm{K}+\mathrm{S}$ model (Dosi et al. $(2010,2013,2017)$, models developed by the Ancona research group (Caiani et al. (2016); Riccetti et al. (2015); Russo et al. (2016)), the MacroAgent-Based Model with Capital and Credit (CC-MABM) (Assenza et al., 2015), the Mark I CRISIS (Complexity Research Initiative for Systemic Instabilities) model (Klimek et al., 2015; Gualdi et al., 2015), Iceace (Erlingsson et al., 2014), Eurace (Cincotti et al., 2012a), and Eurace@UNIBI (Dawid et al., 2018). 
exploit regulatory capital arbitrage to lend more, increasing the amount of credit in the economy and thus making bankruptcies more likely.

To study the securitization process, Eurace financial sector has been enriched with the implementation of a financial vehicle corporation (FVC) and a mutual fund. The FVC buys loans and mortgages from banks and issues ABSs and MBSs to fund its purchases, while mutual fund purchases ABSs and MBSs and issues new shares when in liquidity shortage. Banks decide the amount of credit to securitize endogenously. Being lending activity constrained by a minimum capital requirement, banks can avoid the capital constraints by selling loans or mortgages to the FVC. This is an opportunity to free up their balance sheet from credit and their related risk and, consequently, lend more.

Results show that securitization mechanism is able to impact the business cycle. In the short run, banks sell their assets, thus reducing the risk-weighted assets in their balance sheet and lending more loans and mortgages. Credit increases, as well as the capital income of households that receive the profits of the mutual fund in the form of dividends. Investment and consumption are influenced positively by the new credit triggered by securitization. However, the increased amount of credit amplifies the negative shocks, due to higher loans write-offs probability, caused by the boosted lending activity in the short run. Firms' bankruptcies impact the equity of banks, affecting their ability to grant new loans to consumption goods producers (CGPs), which need credit for their production activity, and mortgages to households, which need credit to purchase housing units. CGPs soon go bankrupt and households see their capital income reduced. The amplitude of securitization's impact in the economy depends on the size of the securitization availment itself. High securitization propensity improves the economic boom during expansions' phases of the business cycle but increases significantly the fragility of the economy, leading to deeper downturns. Low amount of securitization, instead, can have positive effects both in the short and long run.

The article is organized as follows. Section 2 provides a summary of empirical and theoretical literature related to securitization. In Section 3, we introduce the baseline Eurace model with a particular emphasis on the single agents' and sectorial balance sheets based on stock-flow consistency approach. In Section 4, securitization mechanism is described in details, and the new Eurace agents, namely, FVC (or special purpose vehicle) and mutual fund, are presented. In Section 5 we show the results of computational experiments. Section 6 concludes the article with final remarks.

\section{Securitization in empirical and theoretical literature}

In the introduction, we have listed some stock-flow consistent models of securitization and stated the main advantages given by the agent-based approach to catch some relevant effects of securitization process. However, besides stock-flow consistent modeling approaches, an increasing attention has been paid by several empirical and theoretical studies to the securitization activity in the past decades. In this section we provide a survey of literature, focusing on the benefits and costs of securitization, on the securitization impact at micro and macro level and on the role of securitization in the last great financial crisis, explaining how our work fits in this debate.

Securitization market exploded during the 1980s and kept growing in following decades. In Europe, securitization market peaked before the last great crisis, with a total of $€ 818$ billion in new ABSs issuance in 2008. Demand for these assets plummeted after 2008 because of the deterioration in the rating of the collateral behind the various types of ABSs. At the end of 2016, the outstanding amount of European securitized assets was $€ 1.5$ trillion. For comparison, at its peak in 2008, the overall outstanding amount of the ABS market reached more than $€ 2.2$ trillion. $^{2}$ According to the literature, securitization has benefits and costs. On one side, banks can use securitization for conducting regulatory capital arbitrage, by reducing their regulatory capital requirements and lend more (Jones, 2000; Ambrose et al., 2005). Moreover, securitization represents a useful risk management tool for banks because it provides an additional source of funds and increases banks' lending ability (see Loutskina, 2011). On the other side, securitization enhances systemic risk, by reducing banks' incentives to screen loans ex ante and monitoring after lending (Keys et al., 2010). Brunnermeier and Sannikov (2014) study the full equilibrium dynamics of an economy with financial frictions. They find that securitization and financial innovations include tools that, even if designed to better manage risks at individual level, may increase systemic risk. Moreira and Savov (2017) present a macro-finance model in which shadow banking and fragile liquidity transformation in the financial sector boost asset prices and 
create growth in good times at the expense of bad times, and analyse the impact of policy interventions. Another source of systemic risk can be, as stated in Wagner (2007), that banks use the liquidity gained by selling and hedging loans using derivative instruments, to take more risk in primary markets, arising banking instability and the externalities associated with banking failures.

Regarding the securitization impact at micro and macro level, so far the literature on securitization and structured finance has been mainly focused on micro level. In particular, a lot of attention has been paid to risk-taking and transfer (Instefjord, 2005; Chiesa, 2008; Acharya et al., 2013), tranching of derivative securities (Plantin, 2004; DeMarzo, 2005), the role of collaterals for fiscal (Gorton and Ordonez, 2013) and monetary policies (Singh, 2013), and the importance of computing margin requirements for risky collateral in the repo market including systemic risk (Lillo and Pirino, 2015).

In the aftermath of the last great crisis, the debate on the role of securitization has been particularly lively. Demyanyk and Van Hemert (2011) study the negative role of securitization in the deterioration of loans' quality before the last financial crisis of 2008, providing also evidence that the rise and fall of the subprime mortgage market follows a classic lending boom-bust scenario, in which unsustainable growth leads to the collapse of the market. The study of Gorton and Metrick (2012) shows, using empirical data, that securitization led higher uncertainty about bank solvency, increasing the repo haircuts and making the US banking system insolvent during the last great financial crisis. Di Patti and Sette (2016) analyze Italian data and show that the degree to which banks tightened credit supply to nonfinancial firms during crisis is positively related to the share of loans they securitized before the crisis, resulting in lower credit growth, higher interest rates, lower probability of accepting loan applications, and inability of firms to fully compensate the negative credit supply shocks. Despite its negative facade, mainly due to the speculative purpose followed by several financial actors before the financial crisis, sustainable securitization has been indicated as a resource of funding for firms or households (see Segoviano et al., 2013). Moreover, Bertay et al. (2016) emphasize the positive correlation of firms' loans securitization with the economic activity. Among its role as source of funding, a transparent securitization could also help investors, allowing them to diversify their portfolios in terms of risk and return, leading to lower costs of capital, benefits for the economic activity, and a broader distribution of risk (BoE and ECB, 2014). Fujii (2012) suggests regulatory solutions at individual level and extensive reporting requirements of financial institutions to mitigate systemic risk.

In this article, we do not want to focus on the individual banks decisions, but we analyze how securitization affects business cycle, trying to explain how securitization can impact economic activity, either in a positive or negative way. The channels linking securitization and real economy are mainly two (see Bertay et al., 2016 and the related literature). The first one is the change in credit volume of the economy that can result in more consumption for households and more funds for investments for firms. However, excess use of securitization can lead to bankruptcies and worsen economic performance. The second one regards the credit quality, i.e., securitization would help banks to reduce its constrains and allocate capital in the economy in a more efficient way, favoring the flows of capital to most productive firms while sharing the risk among investors. Also in this case, scholars do not completely agree. For instance, Pennacchi (1988) suggests that banks after securitizing are not interested in ensuring the good quality of the borrowers. In our model we focus on the credit volume channel, and we do not pay attention on the differences among borrowers' quality in bank lending decision.

\section{Eurace baseline model}

The Eurace agent-based model and simulator represent a fully integrated macroeconomy composed by several agents that act following behavioral rules and interact through various markets. The model was created during 2006-2009 under the FP6 European Funded Project "EURACE" and since then has been developed to date and strongly improved in the past 3 years under the FP7 European Funded Project "SYMPHONY"(see Ozel et al., 2016; Teglio et al., 2017; Raberto et al., 2018; Ponta et al., 2018). In the model, agents' decision processes are characterized by bounded rationality and limited capabilities of computation and information gathering; thus, agents' behavior follows adaptive rules derived from the management literature about firms and banks, and from experimental economics literature about the behavior of consumers and financial investors.

Moreover, agents interact in different types of markets, i.e., markets for consumption goods and capital good, labor market, credit market, and financial market for stocks and government bonds. In the Eurace ABM model, markets represent the place where agents interact. Markets are based on a decentralized exchange with pairwise trading 
and price dispersion, except for financial market where a centralized Walrasian auctioneer operates and a single price is set at the intersection of the demand and supply curves. In decentralized markets, prices are set by agents on the supply side, by considering a markup on unit costs. For a detailed description of agents' behaviors about decisionmaking hypotheses in real (consumption goods and labor) markets as well as in credit market, see Teglio et al. (2010); Cincotti et al. (2012b); Raberto et al. (2012); Teglio et al. (2017).

The baseline Eurace model includes:

- Households (HHs): They act as consumers and workers. Households buy homogeneous consumption goods from CPGs according to their consumption budget and provide labor force to CPGs. Households can invest in the stock and in the government bond markets. The saving-consumption decision is modeled according to the theory of buffer stock saving behavior, which states that households consumption depends on a precautionary saving motive, determined by a target level of wealth to income ratio (Deaton, 1992; Carroll, 2001). Households can invest their savings in the asset market, by buying and selling equity shares or government bonds. Households' portfolio allocation is modeled according to a preference structure designed to take into account the psychological findings emerged in the framework of behavioral finance and in particular of prospect theory (Kahneman and Tversky, 1979; Tversky and Kahneman, 1992). Households' behavior in the financial market has been thoroughly described in Raberto et al. (2008) and Teglio et al. (2009). In addition, households finance the securitization process by purchasing the shares issued by the mutual fund, when the latter faces a liquidity shortage.

- CGPs: They employ labor and capital goods to produce a homogeneous consumption good according to their production plan. CGPs act as price setters in the sale markets and supply their output following a short-term profit maximizing behavior. In fact, CGPs are characterized by a short-term profit objective and make production and investment plans where expected future revenues are based on backward-looking expectations determined by past sales and prices. In particular, production plans depend on past sales and the inventory stock, along the lines of the inventory management literature (Hillier and Lieberman, 1986), while sale prices are determined by a markup on costs (wages and debt interests, see Plott and Sunder, 1982; Fabiani et al., 2006). Investment plans depend on the cost of capital good and the present value ${ }^{3}$ of the additional foreseen revenues but are limited by both internal ${ }^{4}$ and external financing capabilities. ${ }^{5}$ CGPs can also borrow money from banks to pay production factors and make investments. They are modeled as corporations whose shares are public and traded in the stock market. CGPs can also issue new shares to finance their activities if rationed in the credit market.

Furthermore, two different types of bankruptcies for CGPs are considered in the model, namely, insolvency bankruptcy and illiquidity bankruptcy. The first type (insolvency) occurs when firm's equity goes negative. The second type (illiquidity) is when a firm, even if still characterized by positive net worth, is short of sufficient liquidity to pay its unavoidable financial commitments (taxes and debt service), because it is rationed in the credit market and is unable to sell new shares in the stock market. In both bankruptcy cases, all firm's employees are fired, the firm's physical capital is frozen, and the firm remains inactive for a fixed period of months until new financial capital is raised in the stock market. In the most severe case (insolvency), firm's shareholders are also wiped out, and firm's debt is restructured and set to a new target level which is a fraction of firm's total assets so to get again positive net worth. The amount of the debt exceeding the new target is then written-off, and accordingly the corresponding loans in the asset side of the lending banks are also written-off. Banks lending to the insolvent firm then are subject to a corresponding reduction of their equity base, which may hinder their capacity to supply new credit due to the Basel capital adequacy constraints. Then an insolvency of a big borrower may trigger a widespread credit rationing and a wave of illiquidity bankruptcies with relevant negative impact on both the employment and output levels.

- Capital goods producer (KGP): There is just one type of technology for capital goods. Capital goods are produced on request and therefore do not generate inventories.

- Banks (Bs): Banks supply loans to CGPs to finance their operations and mortgages to households that want purchase housing units, collect private sector deposits (i.e. the liquidity of all private agents), and may borrow from

3 According to empirical surveys (Graham and Harvey, 2001, 2002), the net present value is one of the most popular method used by managers to evaluate investments.

4 Along the lines of Fazzari et al. (2008).

5 The pecking order theory (Myers and Majluf, 1984) is adopted to determine a hierarchy of financial sources for the firm. 
the central bank if in shortage of liquidity through a standing facility. Lending activity by banks is constrained by a minimum capital requirement and depends also on the evaluation of the balance sheet of the borrower. In the market for loans, CGPs apply for credit first to their preferred bank, then if rationed to another selected bank. If CGPs are rationed by both their preferred bank and by a second bank, they will be forced to cut their dividend payment. It is worth noting that, in line with the working of the banking system in a modern capitalist economy (see McLeay et al., 2014), bank lending is not limited by the available liquidity and, whenever a bank grants a loan, a corresponding deposit, entitled to the borrower, is created on the liability side of the bank's balance sheet.

- Government $(G)$ : Government is responsible for the fiscal and welfare policies. The income of the government is given by corporate tax, value-added tax, capital income tax (dividends and bond coupons), and labor tax. The tax payments are done by CGPs, KGP, banks and households, and the government budget income is calculated as the sum of all tax payments. Taxes are collected on monthly basis, while tax rates are revised yearly. Regarding government's expenditures, they include wages for households employed in the public sector that are set as fixed percentage of the total households, unemployment benefits, transfers, and repayment of the government debt (bond coupons). The government observes its budget balance (payment account $M_{G}$ ) every month and if $M_{G}<0$, the government has a budget deficit which can be financed by issuing new government bonds that are sold to the households. The government computes its budget deficit once per month but enters in the bond market on a daily basis. The reason is that if the government enters in the bond market only once per month, there is insufficient demand for the bonds, so the Government may fail to attain its liquidity target. Thus the monthly budget deficit will be financed by bonds on a monthly basis, but there is a smoothing across the month.

- Central Bank (CB): The central bank is the responsible for the monetary policy. It sets the policy rate, which is the cost of liquidity provided to banks. The short-term nominal interest rate follows the Taylor rule (see Taylor (1993) for a discussion) and is set as:

$$
r^{c b}=\pi+a^{\pi}(\pi-\tilde{\pi})-a^{v}(v-\bar{v})
$$

where $\pi$ is the yearly inflation rate for a current month, $\tilde{\pi}$ is the desired rate of inflation, $v$ is the unemployment rate for a current month, and $\bar{v}$ mimics the natural rate of unemployment, or the full-employment rate (that we exogenously set to 0 for simplicity). This version of the Taylor rule departs from the standard one for its use of the unemployment rate instead of the output. The two measures are strongly interconnected, and the unemployment gap is certainly a satisfactory indicator of economic recession. Another role of the central bank is the provision of a standing facility to grant liquidity in infinite supply to commercial banks, when they are in short supply.

\subsection{Eurace stocks and flows matrices}

Each agent is characterized by a double-entry balance sheet with a detailed account of all monetary and real assets as well as monetary liabilities. Monetary and real flows given by agents' behaviors and interactions determine the period by period balance sheet dynamics. A stock-flow model is then created and used to check that all monetary and real flows are accounted for, and that all changes to stock variables are consistent with these flows (see Cincotti et al., 2012b; Raberto et al., 2012 for further details). According to the "stock-flow consistency" approach used in Godley and Lavoie (2012) and post-Keynesian stock-flow consistent modeling (see Caverzasi and Godin, 2015 for a survey), we present four significant matrices that provide an exhaustive description of the model. Table 1 is the agent class balance sheet, i.e., the asset and liability entries of each particular agent type. Table 2 represents the balance sheet matrix, describing all assets and liabilities for each sector (here a sector has to be seen as a class of agents). Table 3, called transaction flow matrix, shows all the stock and monetary flows among agents. Table 4, called equity capital change matrix, reports the variation of agents' net worth between two periods, due to net cash flows, price changes in assets and liabilities, stock changes in real assets, and issues of equity shares.

In the matrix in Table 2 a plus (minus) sign corresponds to agents' assets (liabilities), and each column can be read as the aggregated balance sheet of a specific sector (e.g., households). Rows show assets and claims of assets among sectors, thus generally adding up to 0 . Exceptions are capital and inventories, which are accumulated by CGPs, and households' equity shares of CGPs and banks that do not add up to 0 because of the difference between 
Table 1. Agent class balance sheets

\begin{tabular}{|c|c|c|}
\hline Agent class & Assets & Liabilities \\
\hline $\begin{array}{l}\text { Household } \\
\text { abbrev.: } \mathrm{HH} \\
\text { index: } h=1, \ldots, N_{\text {Hous }}\end{array}$ & $\begin{array}{l}\text { Liquidity: } M_{h} \\
\text { Stock portfolio: } \\
\Sigma_{b} n_{E_{b, b}} p_{E_{b}}+ \\
\Sigma_{f} n_{E_{b, f}} p_{E_{f}}+ \\
n_{E_{b, K}} p_{E_{K}}+ \\
n_{E_{b, D}} p_{E_{D}} \\
\text { Government bonds: } n_{h, G} p_{G} \\
\text { Housing units: } X_{b}\end{array}$ & $\begin{array}{l}\text { Mortgages: } U_{b} \\
\text { Equity: } E_{b}\end{array}$ \\
\hline $\begin{array}{l}\text { Consumption goods producer } \\
\text { abbrev: } \text { CGP } \\
\text { index: } f=1, \ldots, N_{\text {Firm }}\end{array}$ & $\begin{array}{l}\text { Liquidity: } M_{f} \\
\text { Capital goods: } K_{f} \\
\text { Inventories: } I_{f}\end{array}$ & $\begin{array}{l}\text { Debt: } D_{f}=\sum_{b} \ell_{f, b} \\
\text { Equity: } E_{f}\end{array}$ \\
\hline $\begin{array}{l}\text { Capital goods producer } \\
\text { abbrev.: KGP }\end{array}$ & Liquidity: $M_{K}$ & Equity: $E_{K}$ \\
\hline $\begin{array}{l}\text { Financial vehicle corporation } \\
\text { abbrev: } \mathrm{V}\end{array}$ & $\begin{array}{l}\text { Liquidity: } M_{V} \\
\text { Loans: } \mathcal{L}_{V} \\
\text { Mortgages: } U_{V}\end{array}$ & $\begin{array}{l}\text { ABSs: } A B S_{V} \\
\text { MBSs: } M B S_{V} \\
\text { Equity: } E_{V}\end{array}$ \\
\hline $\begin{array}{l}\text { Mutual fund } \\
\text { abbrev.: D }\end{array}$ & $\begin{array}{l}\text { Liquidity: } M_{D} \\
\text { ABSs: } A B S_{D} \\
\text { MBSs: } M B S_{D}\end{array}$ & Equity: $E_{D}$ \\
\hline $\begin{array}{l}\text { Bank } \\
\text { abbrev.: } \mathrm{B} \\
\text { index: } b=1, \ldots, N_{\text {Bank }}\end{array}$ & $\begin{array}{l}\text { Liquidity: } M_{b} \\
\text { Loans: } \mathcal{L}_{b}=\sum_{f} \ell_{b, f} \\
\text { Mortgages: } U_{b}=\sum_{b} U_{b, b} \\
\text { Stock portfolio: } n_{E_{b, V}} p_{E_{V}}\end{array}$ & $\begin{array}{l}\text { Deposits: } \\
\mathcal{D}_{b}=\sum_{b} M_{b, h}+\sum_{f} M_{b, f}+M_{b, K} \\
\text { CB standing facility: } D_{b}=\ell_{b, C B} \\
\text { Equity: } E_{b}\end{array}$ \\
\hline $\begin{array}{l}\text { Government } \\
\text { abbrev: } \mathrm{G}\end{array}$ & Liquidity: $M_{G}$ & $\begin{array}{l}\text { Outstanding government bonds value: } D_{G}=n_{G} p_{G} \\
\text { Equity: } E_{G}\end{array}$ \\
\hline $\begin{array}{l}\text { Central Bank } \\
\text { abbrev: } \mathrm{CB}\end{array}$ & $\begin{array}{l}\text { Liquidity: } M_{C B} \\
\text { Loans to banks: } \ell_{C B}=\sum_{b} \ell_{C B, b} \\
\text { Gov Bonds: } n_{C B, G} p_{G}\end{array}$ & $\begin{array}{l}\text { Outstanding fiat money: Fiat } \\
\text { Deposits: } \mathcal{D}_{C B}=\sum_{b} M_{b}+M_{G} \\
\text { Equity: } E_{C B}\end{array}$ \\
\hline
\end{tabular}

Note: Balance sheets of any agent class characterizing the Eurace economy. Balance sheet entries in the table have a subscript character, which is the index of an agent in the class to which the variable refers. In some cases, we can find two subscript characters, where the second one refers to the index of an agent in another class where there is the balance sheet counterpart. For instance, $D_{f}$ refers to the total debt of firm $f$, i.e., a liability, and $\mathcal{L}_{b}$ refers to the aggregate loans of bank $b$, i.e., an asset. $\ell_{f, b}$ (or $\ell_{b, f}$ ) refers to the loans granted by banks $b$ to firms $f$. Of course, $\sum_{b} \mathcal{L}_{b}=\sum_{f} \ell_{b, f}$ represents an aggregate balance sheet identity, which is verified along the entire simulation. $n_{E_{h x}}$ represents the number of outstanding equity shares of agents $x$ held by households $h$. The market price of the equity shares is given by $p_{E_{x}}$. The stock portfolio's value of household $h$ is then computed as: $\sum_{x} n_{E_{h_{x}}} p_{E_{x}}$. Government bonds' number and market price are given by $n_{G}$ and $p_{G}$, respectively.

market price and book value. However, being the equity shares of KGP, FVC (V), and mutual fund (D) not traded in the financial market, their market price and book value coincide.

In Table 3, the top part (Cash receipts/outlays) describes the flows of revenues (plus sign) and payments (minus sign) that agents get and make. Agents are reported in the columns, and monetary flows are reported in the rows. The result of agents' sector transactions is the net cash flow (NCF). The bottom part of Table 3 (Change in financial/ monetary assets/liabilities) describes the balance sheet changes related to each sector.

\subsection{Money creation}

The central bank can introduce new liquidity (or fiat money) into the system via loans provided to banks when they are in liquidity shortage.

In this case, the economic agents deposit an amount equal to the new fiat money in the banking sector, generating additional liquidity that is deposited at the central bank and, in turn, generates new liquidity of the central bank that is always equal to the amount of fiat money created. This is the reason why in Table 2, the difference between fiat money and central bank liquidity is constant and equal to the initial central bank liquidity. Furthermore, money supply in the economy can variate independently from the fiat money created by the central bank, because it 


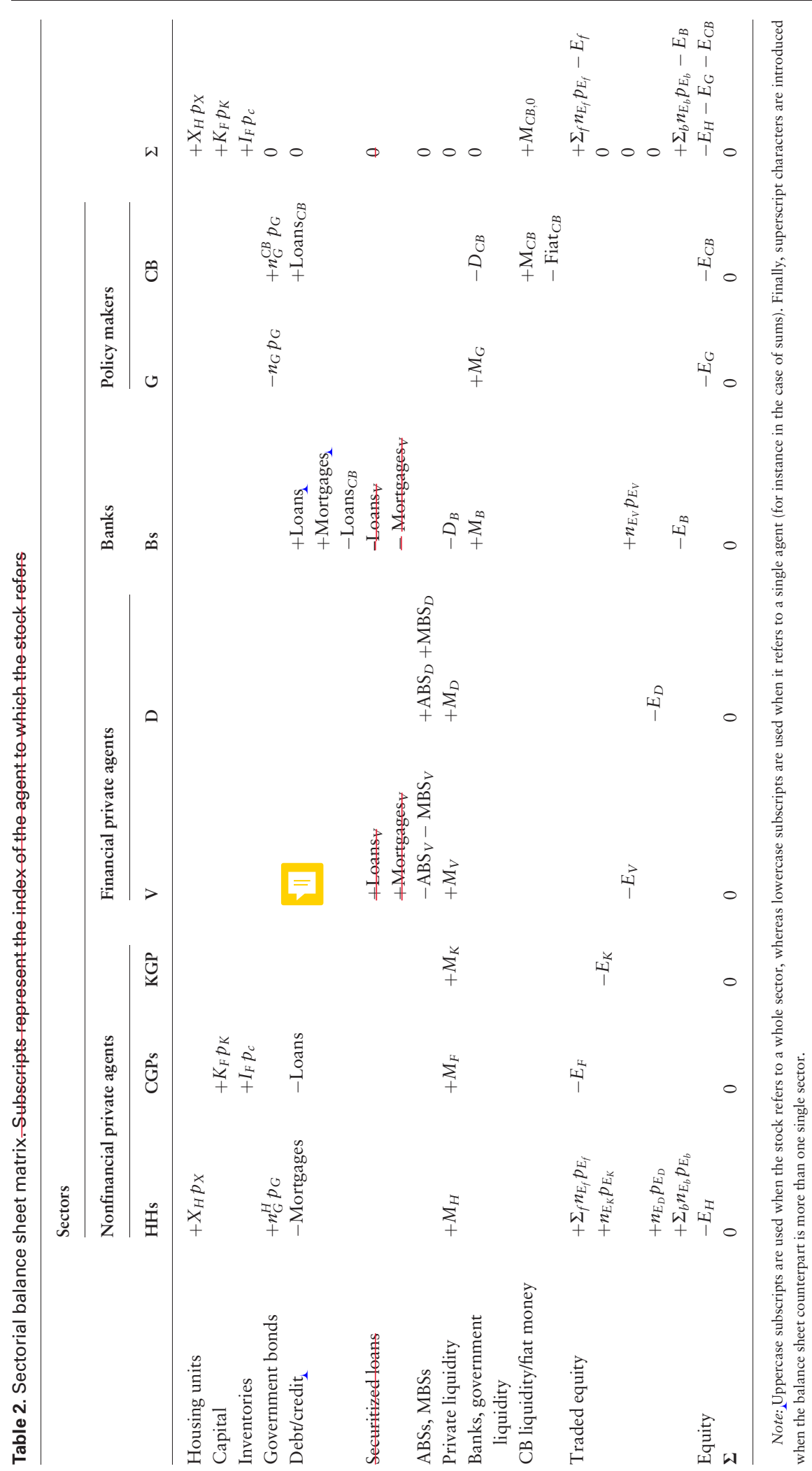




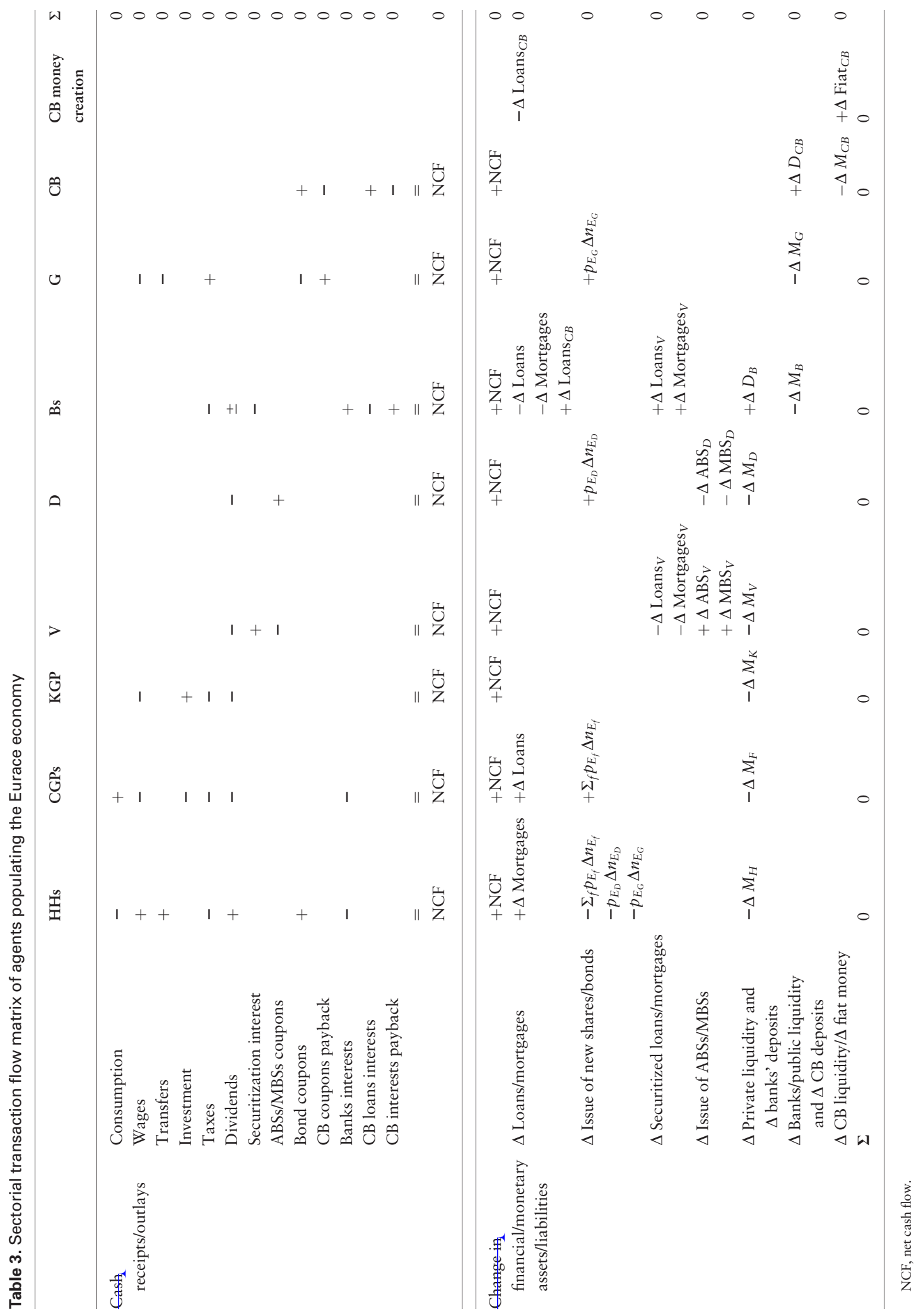




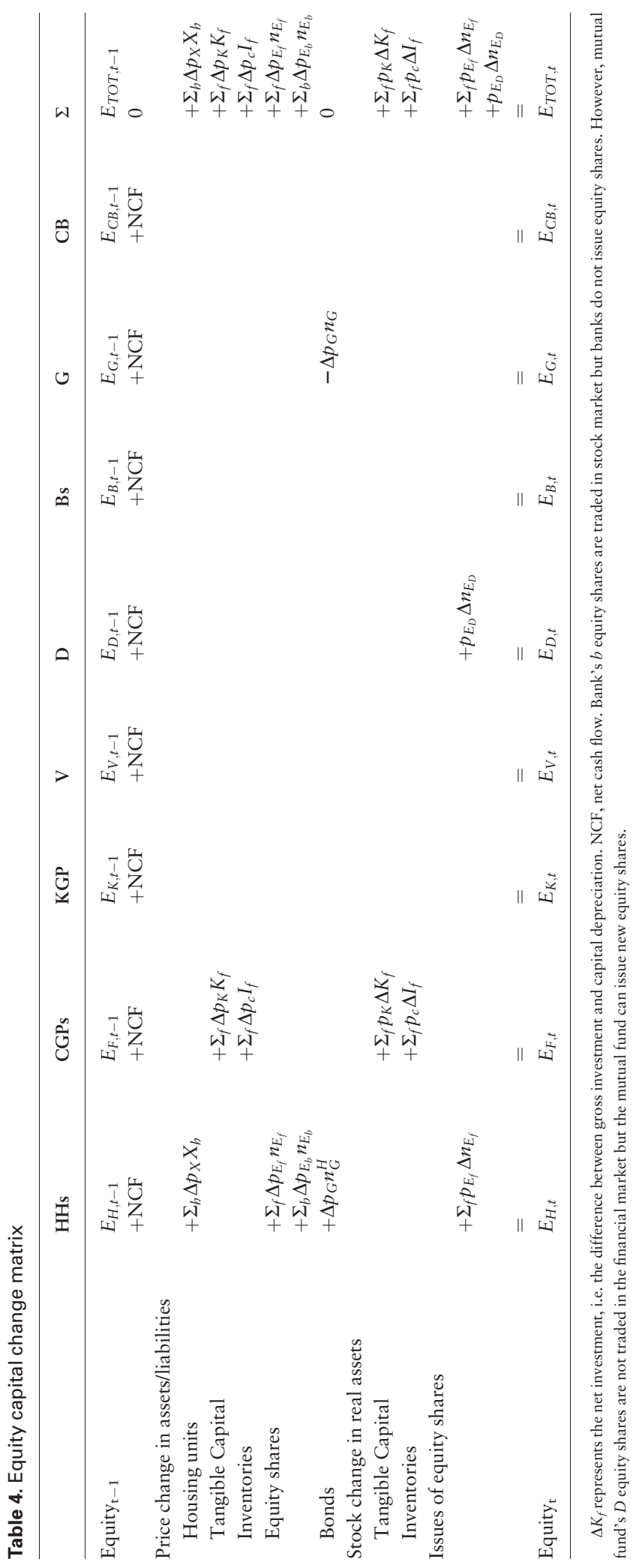


endogenously raises every time a bank grants a new loan, and it decreases when the loan is paid back. Securitization process is able to increase the money supply through the market channel, exploiting the possibility of the banks to sell loans and mortgages to FVC that in turn issue ABSs and MBSs, sold to the mutual fund. Through the capital arbitrage, banks are able to avoid capital requirements and affect the endogenous money creation.

\section{Securitization and money market creation}

To study the securitization mechanism, Eurace baseline model has been enriched with the addition of two agents:

- FVC (V): It carries out securitization transactions. The role of FVC is the transformation of banks' loans and mortgages in ABSs and MBSs. In particular, banks sell to the FVC loans and mortgages that they want to put off their balance sheet. To fund banks' credit purchase, FVC creates pools of loans and mortgages and issues ABSs and/or MBSs.

- Mutual fund (D): It represents the demand side of ABSs and MBSs. It purchases ABSs and MBSs using internal resources and, in case of liquidity shortage, issues new shares that are bought by households. Together with the purchase of ABSs and MBSs, it receives the right to collect the cash flows related to the securitized credit, i.e., principals and interests. Its equity is owned in the form of equity shares by households that receive the profit of the fund through dividends.

Securitization mechanism empowers banks with the possibility to sell loans and mortgages to the FVC, which transfers them out of its balance sheet in the form of ABSs and MBSs, sold to the mutual fund. Thus, banks are able to free their balance sheet from loans and mortgages and their related risk. The relevance of securitization process in Eurace is due to the presence in the model of a realistic banks' capital requirement provision that mimics Basel II/III regulations. In particular, the amount of banks' risk-weighted assets cannot exceed a maximum level with respect to the equity capital, to have a sufficient buffer to cushion possible loans and mortgages write-offs. Thus securitization process can be used by banks for regulatory capital arbitrage. A detailed description of the Eurace credit market and securitization process follows.

\subsection{Credit supply}

Let us consider a bank $b$ with equity $E_{b}$ and risk-weighted portfolio $W_{b}$, consisting of risk-weighted loans $W_{b, \mathcal{L}}$ and mortgages $W_{b, U}$, such that:

$$
W_{b}=W_{b, \mathcal{L}}+W_{b, U} .
$$

Suppose that a CGP sends a loan request amount $\lambda_{f}$ to the bank $b$. Let us assume that $\omega_{\lambda_{f}}$ is the risk weight of loan $\lambda_{f}$ (i.e., accounts for the financial fragility of the prospective borrower); then we set $\omega_{\lambda_{f}}$ to depend on the borrower's default probability as follows:

$$
\omega_{\lambda_{f}}=2.5\left(\pi_{f}\right)^{3},
$$

where $\pi_{f}$ represents the default probability of the borrower based on its leverage, along the lines of the Moody's KMV (Kealhofer, McQuown and Vasicek) model (Saunders and Allen, 2010):

$$
\pi_{f}=\frac{D_{f}+\lambda_{f}}{D_{f}+\lambda_{f}+E_{f}},
$$

where $D_{f}$ and $E_{f}$ are the amount of debt and equity of the CGP $f$. Equation 3 represents a cubic function approximating the so-called Basel II internal ratings approach (see Yeh et al., 2005). In this way, different credit ratings are assigned to different borrowers, and the risks associated to their loans have different weights in banks balance sheet. Bank $b$ is allowed to lend up to the amount $\ell_{b f} \leq \lambda_{f}$ provided that its equity (capital base) is at least a fraction $k$ of $W_{b}+\omega_{\lambda_{f}} \ell_{b f}$ :

$$
W_{b}+\omega_{\lambda_{f}} \ell_{b f} \leq \alpha E_{b},
$$

where $\alpha$ is the inverse of $k$, i.e., $\alpha=1 / k$. 
Besides CGP, households can send credit requests to banks. Whenever they enter in the housing market, they can buy house units and, in case their liquidity is lower than the offered price, they ask for a mortgage (see Ozel et al., 2016). Let us assume that $\hat{U}_{b h}$ is the mortgage asked by the potential borrower (household $h$ ) to the bank $b$. Bank $b$ can grant the mortgage amount $\hat{U}_{b h}$ to household $b$ only if its capital requirement is satisfied, following the same condition expressed in equation (5) for loans to CGPs:

$$
W_{b}+\omega_{\hat{U}_{b}} \hat{U}_{b b} \leq \alpha E_{b} .
$$

Differently from CGP loans, risk weight of household mortgages $\omega_{\hat{U}_{b}}$ is assumed constant and equal to 0.5.

However, a flow control measure, namely, debt-service-to-income (DSTI), checks incomes and debt payments of the household for the upcoming quarter. In particular, banks can provide mortgages only if the total mortgage payments of the applicant are lower than a DSTI ratio of his income, i.e.,

$$
R_{U_{b}}+R_{\hat{U}_{b}} \leq \operatorname{DSTI}\left(Z_{l}+Z_{e}\right)
$$

where $R_{U_{b}}+R_{\hat{U}_{b}}$ is the quarterly payments (principal and interests) related to both present mortgages $U_{b}$ of household $h$ and the new mortgage $\hat{U}_{b} \cdot Z_{l}+Z_{e}$ is the sum of quarterly labor and capital income after taxes.

\subsection{Securitization mechanism}

As stated in the equations (5) and (6), bank's lending activity is limited by the ratio of its risk-weighted assets and equity, according to the regulatory capital requirements. The ceiling of risk-weighted assets for the bank is given by $\alpha$ times its equity capital, i.e., $\alpha E_{b}$. Thus, from a regulatory perspective, bank is constrained by the following rule: $W_{b} \leq \alpha E_{b}$. With the introduction of the securitization mechanism, the bank can put off its balance sheet the amount of risk-weighted assets that exceeds the ceiling. Moreover, we want to add a behavioral rule, by considering different thresholds, computed quarterly as a fraction of the ceiling. Therefore, we introduce an exogenous securitization propensity parameter $\mu$. According to $\mu$, the bank's threshold is given by $(1-\mu) \alpha E_{b}$. The higher the value of $\mu$, the lower will be the threshold of the bank, resulting in more securitization. In fact, whenever bank's risk-weighted assets exceed the threshold, the bank computes the amount $S_{b}$ of risk-weighted assets that it want to sell to the FVC as:

$$
\left\{\begin{array}{lll}
S_{b}=W_{b}-(1-\mu) \alpha E_{b} & \text { if } & W_{b}>(1-\mu) \alpha E_{b} \\
S_{b}=0 & \text { if } & W_{b} \leq(1-\mu) \alpha E_{b}
\end{array}\right.
$$

We define $\mathcal{L}_{b}$ and $U_{b}$ as the amount of loans and mortgages in bank $b$ balance sheet. The fraction of loans $\left(\mathcal{L}_{S_{b}}\right)$ and/or mortgages $\left(U_{S_{b}}\right)$ that the bank will securitize and sell to the FVC is computed as the ratio between $S_{b}$ and the bank's risk-weighted assets and is uniformly distributed among bank's loans and/or mortgages. In particular, we consider three settings, depending on the type of credit securitized:

1. Loans securitization (LS): Only loans are sold to FVC and securitized:

$$
\left\{\begin{array}{llll}
\mathcal{L}_{S_{b}}=\left(\frac{S_{b}}{W_{b, \mathcal{L}}}\right) \mathcal{L}_{b} & \text { if } & W_{b, \mathcal{L}}>S_{b} \\
\mathcal{L}_{S_{b}}=\mathcal{L}_{b} & \text { if } & W_{b, \mathcal{L}} \leq S_{b}
\end{array}\right.
$$

2. Mortgages securitization (MS): Only mortgages are sold to FVC and securitized:

$$
\left\{\begin{array}{lll}
U_{S_{b}}=\left(\frac{S_{b}}{W_{b, U}}\right) U_{b} & \text { if } & W_{b, U}>S_{b} \\
U_{S_{b}}=U_{b} & \text { if } & W_{b, U} \leq S_{b}
\end{array}\right.
$$

3. Total securitization (TS): Both loans and mortgages are sold to FVC and securitized:

$$
\begin{aligned}
\mathcal{L}_{S_{b}} & =\left(\frac{S_{b}}{W_{b}}\right) \mathcal{L}_{b} \\
U_{S_{b}} & =\left(\frac{S_{b}}{W_{b}}\right) U_{b}
\end{aligned}
$$


FVC funds the purchase of loans and mortgages by issuing ABSs and/or MBSs. The securitized assets are then sold to the mutual fund. This process allows the bank to free its balance sheet from an amount of risk-weighted assets equal to $S_{b}$, decreasing the amount of $W_{b}$ and allowing the bank to lend more, according to equations (5) and (6). Thus new money can be created in the system by a process that involves agents outside the banking sector.

\subsection{Stock-flow consistency of securitization process}

To ensure the stock-flow consistency of the securitization mechanism, and to model a reliable securitization process in a macroeconomic large-scale simulator, we have implemented the FVC and the mutual fund in a more stylized way compared with the credit and banking sector, but still consistent with the research question, that focuses on banks' ability to exploit securitization (at different intensity levels) for capital arbitrage purposes, and on the effects of this process on the credit and business cycles.

In particular, the mutual fund is endowed with an initial provision of liquidity that is able to absorb an amount of securitized products for a given, limited, period. In our simulations, this period corresponds to two quarters, computed with $\mu$ equal to $100 \%$. In addition, the mutual fund can issue new shares to increase its liquid resources and therefore to finance ABSs and MBSs purchases. The fund aims at maintaining its liquidity at the target level, ${ }^{6}$ issuing new shares when the liquidity goes down below the target.

Let us assume that $M_{D}^{*}$ is the liquidity target of the mutual fund, while $M_{D}$ represents its current level of liquid resources. In each quarter, mutual fund computes its liquidity needs $L_{D}$ as:

$$
\left\{\begin{array}{lll}
L_{D}=M_{D}^{*}-M_{D} & \text { if } & M_{D}^{*}>M_{D} \\
L_{D}=0 & \text { if } & M_{D}^{*} \leq M_{D}
\end{array}\right.
$$

Therefore, $L_{D}$ represents the amount of liquidity that the fund should rise by issuing new shares. The rationale behind this choice is to avoid linking directly each quarterly securitization process to the issuing of new shares, therefore giving rise to frequent shocks on household net income, but to let the fund to periodically adjust its liquidity level to have always enough resources to purchase ABSs and MBSs. In fact, the liquidity of the fund decreases whenever new securitized products are purchased, while it increases each time households and/or CGPs repay loan and/or mortgage installments. The fund computes quarterly the needed liquidity to reach its target, and, accordingly, issues new shares that are bought by the households at the face value ${ }^{7}$ and distributed among them proportionally to their net income. The shares owned by households give them the right to receive the earnings of the mutual fund, which are given by the interest payments on the credit associated with securitized products. This payment of dividends ensures that the fund does not accumulate any profit.

Two relevant points deserve attention: first, we do not model a market for ABSs and MBSs with related prices and a behaviorial specification of the demand side; second, the demand side is made by households whose role as fund's shares investors does not involve a portfolio choice model but is limited to a sort of compulsory purchase. However, it is worth remarking that the purchase of ABSs and MBSs by the mutual fund is definitely not a free lunch and is not $100 \%$ guaranteed, and it has also effects on the economy. In particular, households are available to buy mutual fund's shares only within a certain proportion of their net income; otherwise, mutual fund may not be able to fully finance the purchase of ABSs and MBSs, and securitization stops until new funds are raised by the mutual fund itself. Furthermore, the purchase of fund's shares reduces households' consumption budget, and then affecting aggregate consumption in the economy, although this effect in the medium term is counterbalanced by dividend income deriving from the profits of the mutual fund. Generally speaking, we want to emphasize that our aim is to analyze how different levels of securitization, entailed by securitization propensity $\mu$, impact the credit market and the business cycle, regardless of a particular behavioral model of demand for derivative products. The novelty compared to the endogenous credit-money approach, already studied with Eurace (see Raberto et al., 2012), is the fact that the

6 We define the target level as the fixed amount of "operating liquidity" that is needed to carry out the securitization process for a quarter, which corresponds to half of the initial provision of liquidity. It is worth noting that the fund uses this liquidity simply as a buffer for its securitization activity but relies on share issuing for financing new purchases. As the securitization process is operating quarterly, our parsimonious choice guarantees the operations of the fund but limits an unrealistic accumulation of liquidity.

7 The face value is computed as the ratio between the nominal value of the mutual fund assets divided by the number of outstanding shares. 
parties involved are not only banks and borrowers, but also a system that operates outside the banking sector and allows banks to overcome regulatory requirements, with considerable impact on the real economy.

Concerning the stock-flow consistency of the securitization process, it is worth to point out that securitization mechanism does not only include the credit transfer but also the payment of the related flows. When a bank sells

credit, it computes the ratio between securitized loans (mortgages) and total loans (mortgages), i.e., $\phi_{l}=\frac{\mathcal{L}_{s_{b}}}{\mathcal{L}_{b}}$ and $\phi_{m}=\frac{U_{S_{b}}}{U_{b}}$. They represent the fractions of loans or mortgages securitized (quarterly) over the total loans or mortgages held by the bank $b$. But they also represent the fraction of interests, principals, and installments that borrowers pay to banks and that shall be paid to the owner of securitized credit, i.e., mutual fund, through the intermediation of FVC. In Eurace, every loan and mortgage has a fixed period of repayments, i.e., 24 months for loans and 240 months for mortgages. Firms pay monthly the debt interests and debt installments until the period of repayment is termined. Also households make monthly mortgage payments that include both interests and the principal installment, where the latter is fixed and determined by the ratio between the initial mortgage amount and mortgage duration in months. ${ }^{8}$ Given that every bank can grant loans and mortgages on daily basis, whenever securitization is active and a bank sells a fraction of loans and mortgages to the FVC $\left(\phi_{l}\right.$ and $\left.\phi_{m}\right)$, that stock of credit includes a portion of several loans and/or mortgages, characterized by different amounts, residual months left to be repaid, and interests. We keep track of each of those variables for each borrower when securitizing credit. This process has a primary importance, since the fraction of credit securitized must be equal to the fraction of installments, principals, and interests of loans and/or mortgages involved in securitization and repaid monthly. This process ensures that the stock-flow consistency is always satisfied (see Tables 2-4).

In the same period when FVC receives securitized credits, it pools all those credits together creating ABSs (using loans) and MBSs (using mortgages). Each pool of credit corresponds to the sum of quarterly securitized credit. ABSs and MBSs are not modeled as new bonds created by FVC, homogenized in terms of expiration and interest rate. They represent the sum of the pooled credit of each securitization activity. But, of course, each pool of credit is backed by the correspondent cash flow of loans' and/or mortgages' principals and interests. After pooling credit, FVC sells ABSs and MBSs to the mutual fund and then pays the bank. ABSs and MBSs, at the current stage, are not traded in the financial market. Therefore, they are sold at their face value to the mutual fund that keeps them in its balance sheet after purchasing them.

Finally, securitized loans' and mortgages' write-offs burden both on banks and mutual fund. In fact, since each securitization activity involves a stock composed by several loans and mortgages, whenever a credit is not repaid by the borrower, it is written-off by both banks and mutual fund, according to $\phi_{l}$ and $\phi_{m}$.

\section{Computational experiments}

Results are based on Monte Carlo computational experiments, i.e., simulations were run using different seeds of the pseudo-random number generator for each scenario. We consider three different settings for securitization, as explained in Section 4.2:

- LS: Only loans are securitized.

- MS: Only mortgages are securitized.

- TS: Both loans and mortgages are securitized.

Moreover, we consider four values of $\mu(0 \%, 15 \%, 30 \%$, and $45 \%)$; thus there are a total of 12 scenarios. Simulations run for a time span of 15 years and 50 seeds per scenario have been used, for a total of 600 simulations. Furthermore, simulations have been performed with the following settings: 3000 households, 50 CGPs, 3 banks, 1 capital good producer, 1 government, and 1 Central Bank. We present results using time trajectories, boxplots, and averages. Trajectories are presented only for one seed and TS scenario; they provide a clear comparison of the different TS scenarios across time. Furthermore, for statistical robustness, a set of boxplots is presented. They show, for three settings of securitization (LS, MS, and TS) and four values of $\mu(0,15 \%, 30 \%$, and $45 \%)$, the distribution of economic and financial variables over the 50 seeds used to initialize the pseudo-random number generator. Boxplots

8 However, in the housing market, households can sell their house units and extinguish a mortgage before the fixed period of repayment. 
report time averages, and we have considered three time spans, each of them starting from Year 3 and lasting until the end of Year 5, Year 10, and Year 15. Therefore, time spans include 2, 8, and 13 years, respectively. In the boxplots, the top of the rectangle indicates the third quartile, the horizontal line inside the rectangle indicates the median, and the bottom of the rectangle indicates the first quartile. The vertical line that extends to the top of the rectangle indicates the maximum value, and another vertical line that extends to the bottom of the rectangle indicates the minimum value. The points inside the boxplots represent the yearly averages. Simulations run for a time span of 15 years, but for the first 3 years banks are not allowed to sell credit to FVC; thus there are 3 years of common transition phase, which we do not consider in the analysis. Simulation can diverge at the beginning of Year 4, when banks can sell credit to FVC, and thus, the distinction among securitization scenarios is enabled. In this way, there is a second 12-year period, which is different for each scenario but originates from the same initial conditions. In the description of results, we refer to credit as the sum of loans and mortgages. In-BS credit represents the credit accounted in banks' balance sheet, while off-BS credit is the credit securitized and put off banks' balance sheet. Total credit represents the sum of in-BS credit and off-BS credit. Finally, since in the explanations of computational experiments' results we often refer to the synchronization among different variables during the business cycle, we have performed a crosscorrelation analysis, to objectively assess the correlation of those variables for different time lags.

Figure 1 and Table 5 show the correlation structure of the real gross domestic product (GDP). We consider monthly time series' averages of 50 simulation runs detrended by using the Hodrick-Prescott (HP) filter, one for each seed used for the pseudo-random number generator. In Figure 1, we show the cross-correlations for 20 positive and negative lags, as well as the upper and lower confidence bounds. Table 5 summarizes the results of Figure 1 and includes also the standard error of Monte Carlo simulations. We observe that real GDP is positively correlated with consumption and investments, and it is anti-correlated with the unemployment rate. GDP also shows a positive correlation with loans to firms, which are leading the business cycle expansion, while it shows an anti-correlation with firms' bankruptcies, which are coincidental with a cycle contraction. This results are in line with main stylized facts on credit and business cycle (see for instance Watson and Stock, 1999; Napoletano et al., 2006; Cappiello et al., 2010; Uribe and Schmitt-Grohe, 2017).
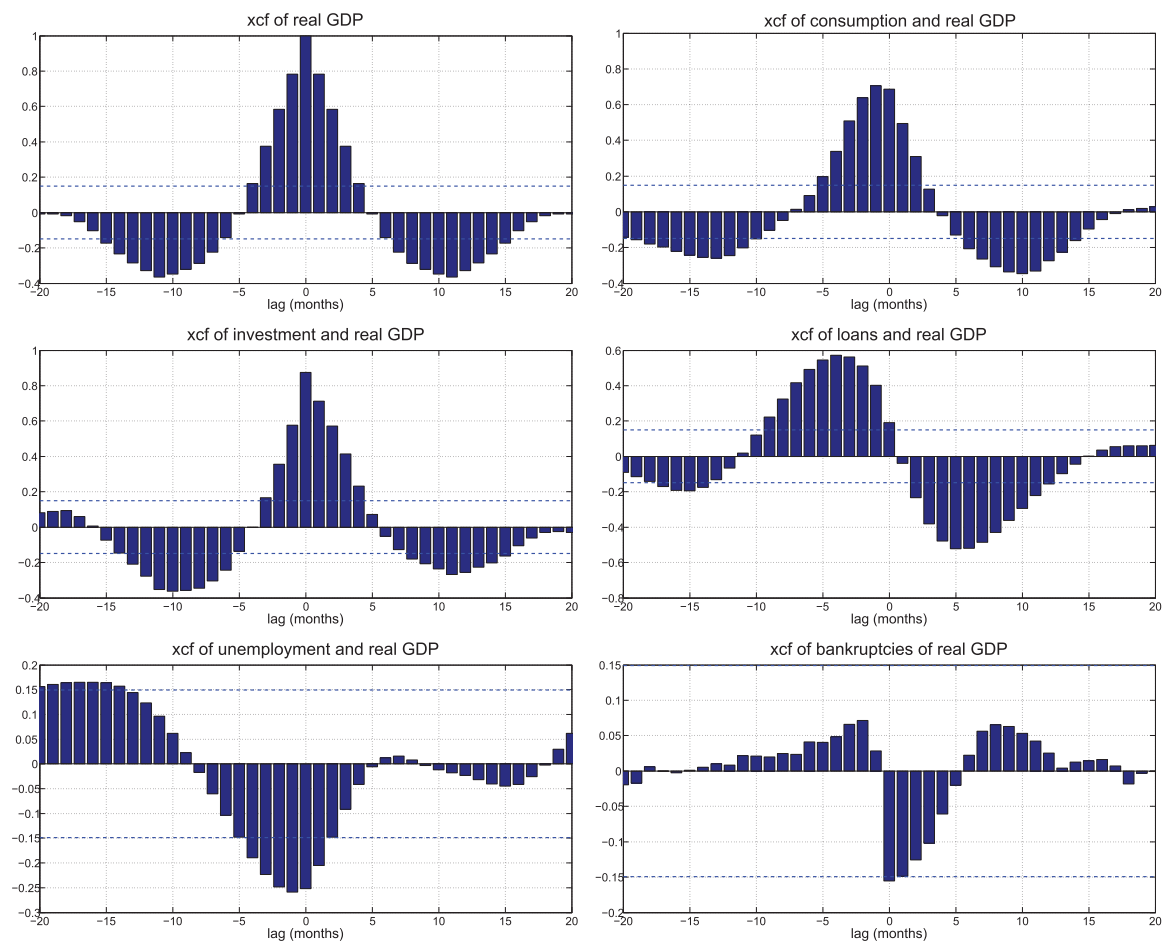

Figure 1. Cross-correlations. Time series considered are monthly and HP filtered. 
Table 5. Cross-correlation of HP filtered series vs. real GDP

\begin{tabular}{|c|c|c|c|c|c|c|c|c|c|}
\hline Filtered series & $t-4$ & $t-3$ & $t-2$ & $t-1$ & $t$ & $t+1$ & $t+2$ & $t+3$ & $t+4$ \\
\hline GDP & $\begin{array}{c}0.1650 \\
(0.0134)\end{array}$ & $\begin{array}{c}0.3754 \\
(0.0124)\end{array}$ & $\begin{array}{c}0.5842 \\
(0.0105)\end{array}$ & $\begin{array}{c}0.7828 \\
(0.0078)\end{array}$ & $\begin{array}{c}1.0000 \\
(0.0000)\end{array}$ & $\begin{array}{c}0.7828 \\
(0.0078)\end{array}$ & $\begin{array}{c}0.5842 \\
(0.0105)\end{array}$ & $\begin{array}{c}0.3754 \\
(0.0124)\end{array}$ & $\begin{array}{c}0.1650 \\
(0.0134)\end{array}$ \\
\hline Consumption & $\begin{array}{c}0.3390 \\
(0.0224)\end{array}$ & $\begin{array}{c}0.5100 \\
(0.0199)\end{array}$ & $\begin{array}{c}0.6396 \\
(0.0159)\end{array}$ & $\begin{array}{c}0.7047 \\
(0.0116)\end{array}$ & $\begin{array}{c}0.6871 \\
(0.00114)\end{array}$ & $\begin{array}{c}0.4950 \\
(0.0128)\end{array}$ & $\begin{array}{c}0.3105 \\
(0.0106)\end{array}$ & $\begin{array}{c}0.1281 \\
(0.0091)\end{array}$ & $\begin{array}{r}-0.0219 \\
(0.0083)\end{array}$ \\
\hline Investment & $\begin{array}{r}-0.0012 \\
(0.0075)\end{array}$ & $\begin{array}{c}0.1658 \\
(0.0081)\end{array}$ & $\begin{array}{c}0.3570 \\
(0.0079)\end{array}$ & $\begin{array}{c}0.5763 \\
(0.0077)\end{array}$ & $\begin{array}{c}0.8759 \\
(0.0043)\end{array}$ & $\begin{array}{c}0.7133 \\
(0.0089)\end{array}$ & $\begin{array}{c}0.5714 \\
(0.0126)\end{array}$ & $\begin{array}{c}0.4137 \\
(0.0147)\end{array}$ & $\begin{array}{c}0.2328 \\
(0.0156)\end{array}$ \\
\hline Loans & $\begin{array}{c}0.5711 \\
(0.0083)\end{array}$ & $\begin{array}{c}0.5622 \\
(0.0077)\end{array}$ & $\begin{array}{c}0.5123 \\
(0.0084)\end{array}$ & $\begin{array}{c}0.4012 \\
(0.0099)\end{array}$ & $\begin{array}{c}0.1920 \\
(0.0109)\end{array}$ & $\begin{array}{r}-0.0392 \\
(0.0121)\end{array}$ & $\begin{array}{r}-0.2346 \\
(0.0129)\end{array}$ & $\begin{array}{r}-0.3815 \\
(0.0135)\end{array}$ & $\begin{array}{r}-0.4774 \\
(0.0135)\end{array}$ \\
\hline Unemployment & $\begin{array}{r}-0.1895 \\
(0.0102)\end{array}$ & $\begin{array}{r}-0.2237 \\
(0.0092)\end{array}$ & $\begin{array}{r}-0.2481 \\
(0.0079)\end{array}$ & $\begin{array}{r}-0.2591 \\
(0.0072)\end{array}$ & $\begin{array}{r}-0.2518 \\
(0.0077)\end{array}$ & $\begin{array}{r}-0.2052 \\
(0.0072)\end{array}$ & $\begin{array}{c}-0.1477 \\
(0.059)\end{array}$ & $\begin{array}{r}-0.0914 \\
(0.0048)\end{array}$ & $\begin{array}{r}-0.0412 \\
(0.0042)\end{array}$ \\
\hline Bankruptcies & $\begin{array}{c}0.0483 \\
(0.0179)\end{array}$ & $\begin{array}{c}0.0658 \\
(0.0185)\end{array}$ & $\begin{array}{c}0.0715 \\
(0.0179)\end{array}$ & $\begin{array}{c}0.0281 \\
(0.0142)\end{array}$ & $\begin{array}{r}-0.1552 \\
(0.0171)\end{array}$ & $\begin{array}{r}-0.1484 \\
(0.0226)\end{array}$ & $\begin{array}{r}-0.1260 \\
(0.0228)\end{array}$ & $\begin{array}{r}-0.1022 \\
(0.0210)\end{array}$ & $\begin{array}{r}-0.0606 \\
(0.0166)\end{array}$ \\
\hline
\end{tabular}

Note: Standard errors of Monte Carlo simulations in parentheses.

\subsection{Regulatory capital arbitrage}

Before delving into the results regarding banks' regulatory capital arbitrage, we shall explain in detail the effects of securitization on banks' equity and assets, to provide a clearer picture of their role in credit lending mechanism. Boxplots in Figure 2 show the evolution of banks' equity for three time spans (Years 5, 10, and 15) and four securitization propensities $(0 \%, 15 \%, 30 \%$, and $45 \%)$. A vertical inspection of the boxplots shows that banks' equity strongly increases in the scenario featured by the lowest securitization propensity $(\mu=0 \%)$, almost doubling in Year 15. In this scenario, the growth of banks' equity is clearly related to the increase in banks' total assets, which is in turn related to the general growth of the economic activity. When total assets of banks increase, banks have to raise their equity to comply with the capital requirements. The fact that banks' assets increase is certified in boxplots in Figures 3-5, while the fact that banks maintain an equity to in-BS credit ratio slightly superior to $10 \%$ is shown in boxplots in Figure 6. The mechanism that allows banks to increase their equity to respect capital requirements is based on retained earnings; therefore, when a bank falls short in capital, it retains earnings to increase it. When we consider the practice of securitization, a part of banks' assets is transferred to the FVC, and therefore, banks diminish the amount of in-BS assets while increasing the amount of off-BS assets, as clearly displayed in Figure 7 and remarked in boxplots in Figures 8 and 9. Moreover, Figure 10 includes the quarterly amount of loans and mortgages securitized. These flow representations allow to better assess the link between securitized credit and macroeconomic variables, such as consumption and investment, across the different phases of the business cycle.

Lower in-BS assets lead to lower equity capital needs for banks; thus the equity growth is lower than in case of $\mu=0 \%$. We see from Figure 11 and boxplots in Figure 2 that the higher the securitization propensity, the lower the need to increase equity with respect to the initial value, because of an increasing portion of total assets that flows out of the balance sheets and out of regulatory control. In the extreme case of $\mu=45 \%$, banks do not need to raise equity at all because the off-BS assets fraction is sufficiently high to compensate the increase of loans and mortgages by banks, which would push up equity requirements. We report the level of in-BS credit (boxplots in Figure 12) to better catch the similarity of pattern with respect to banks' equity (boxplots in Figure 2). Therefore, an increase of securitization propensity implies that banks do not need to increase equity as much as in the scenario of $\mu=0 \%$. The consequence is an increase of banks' fragility and systemic risk, since credit institutions have lower equity to bear firms' bankruptcies during recessions, as better outlined in Sections 5.2 and 5.3.

Regarding the purchase of ABSs and MBSs, as stated in Section 4.3, the mutual fund uses its liquid resources (boxplots in Figure 13) and, if necessary, issues new shares (boxplots in Figure 14). Both figures show that for higher securitization propensity and time span, the funding needs of the mutual fund increase, and therefore, more shares are issued, especially in TS scenario, that is the one where more credit is securitized, as explained afterward. Furthermore, the new shares issued by the fund are bought by households that invest a part of their net income in those equity shares, as shown in boxplots in Figure 15, that display the size of households' purchases in relative terms, reaching the $10 \%$ in the extreme case of $\mu$ equal to $45 \%$ and time span of 15 year in TS scenario. Although 


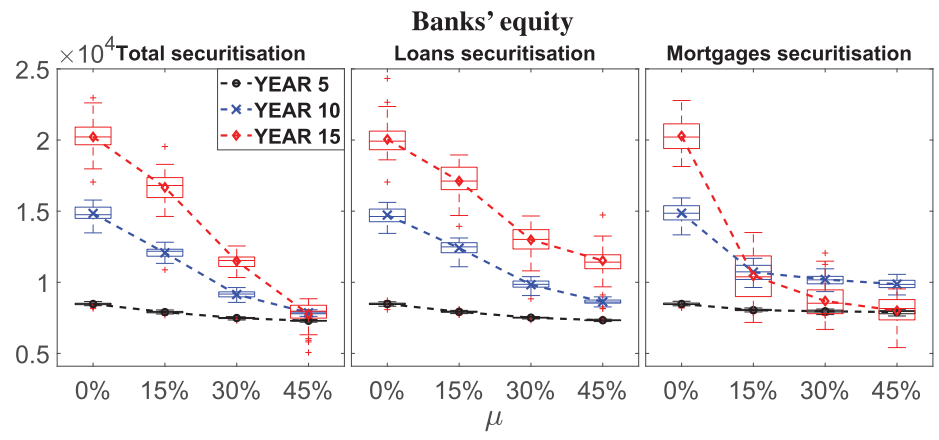

Figure 2. Boxplots and means of banks' equity, for three different time spans $(5,10$, and 15 years), three typologies of securitization (TS, LS, and MS), and four values of $\mu(0 \%, 15 \%, 30 \%$, and $45 \%)$.

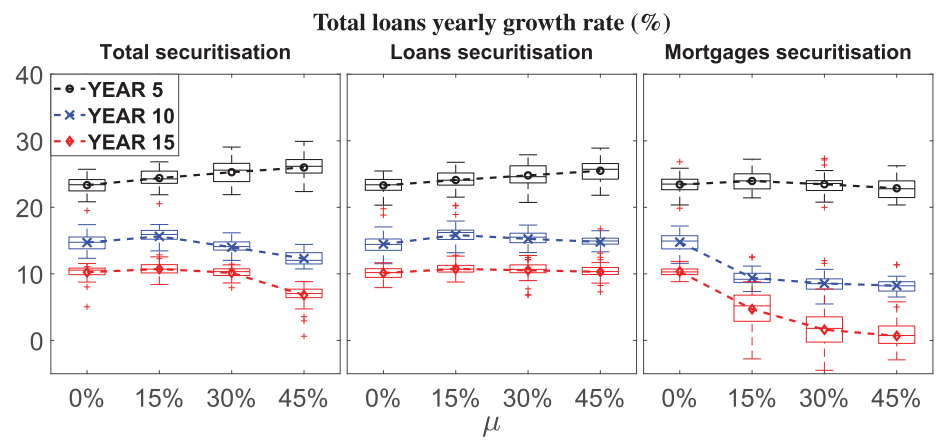

Figure 3. Boxplots and means of total loans yearly growth rate, for three different time spans (5, 10, and 15 years), three typologies of securitization (TS, LS, and MS), and four values of $\mu(0 \%, 15 \%, 30 \%$, and $45 \%)$.

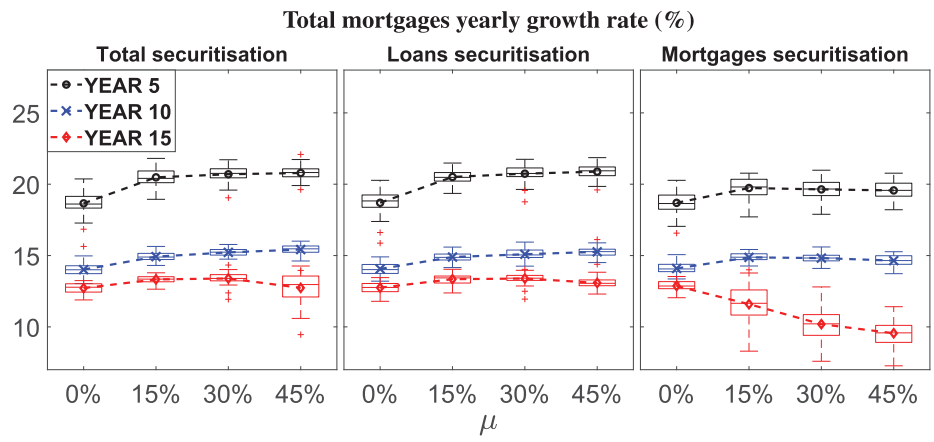

Figure 4. Boxplots and means of total mortgages yearly growth rate, for three different time spans $(5,10$, and 15 years), three typologies of securitization (TS, LS, and MS), and four values of $\mu(0 \%, 15 \%, 30 \%$, and $45 \%)$.

households spend more net income on shares as the securitization propensity increases, it is worth noting that dividends received by the same households also increase, therefore not leading to a substantial modification of households' consumption decision (see boxplots in Figure 16).

Time series in Figure 17 show the ratio between off-BS credit and total credit. The toothed patterns are determined by the timing of securitization activation. Every quarter, banks sell credit to the FVC, increasing the amount of off-BS credit as well as its ratio with respect to the total credit. Among two quarters, the payments of credit 


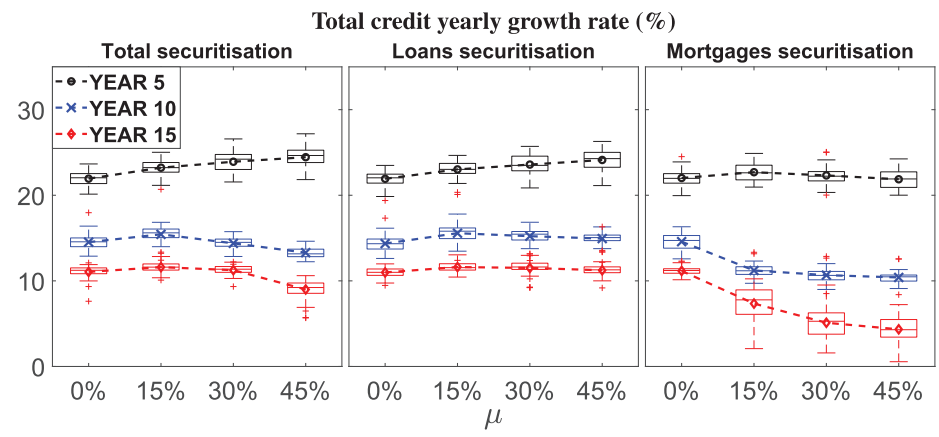

Figure 5. Boxplots and means of total credit yearly growth rate, for three different time spans (5, 10, and 15 years), three typolog* of securitization (TS, LS, and MS), and four values of $\mu(0 \%, 15 \%, 30 \%$, and $45 \%)$.

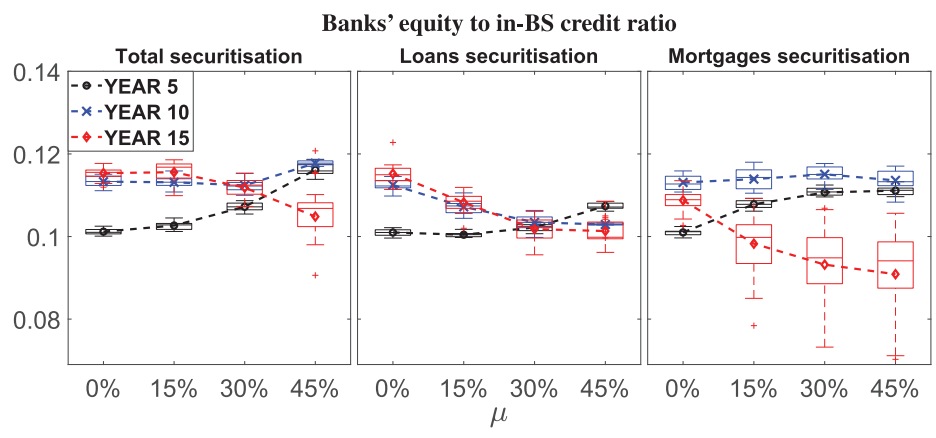

Figure 6. Boxplots and means of banks' equity to in-BS credit ratio, for three different time spans $(5,10$, and 15 years), three typologies of securitization (TS, LS, and MS), and four values of $\mu(0 \%, 15 \%, 30 \%$, and $45 \%)$.
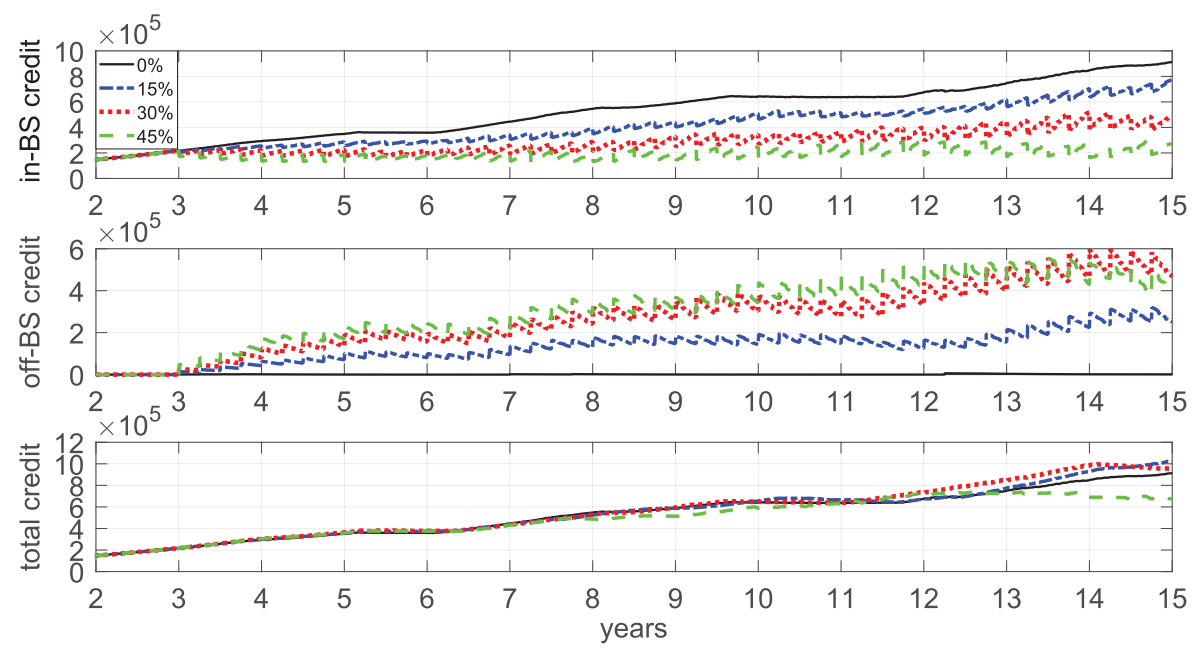

Figure 7. In-BS credit (top panel), ABSs and MBSs in mutual funds balance sheet (middle panel), and total credit (bottom panel). Four values of $\mu$ are shown: $0 \%, 15 \%, 30 \%$, and $45 \%$.

installments decrease the amount of off-balance sheet credit, with the result of a lower value of the ratio. Higher values of securitization propensity $\mu$ raise the amount of off-BS credit. It is worth pointing out that, as explained in Section 4 , also for $\mu$ equal to $0 \%$ banks can sell credit (Figure 17), but they rarely do it, because their risk-weighted assets are usually lower than the ceiling. Boxplots in Figure 9 show the ratio of off-BS credit and total credit also for the LS and MS settings, but the ratio is lower with respect to TS setting, because only loans or mortgages are 


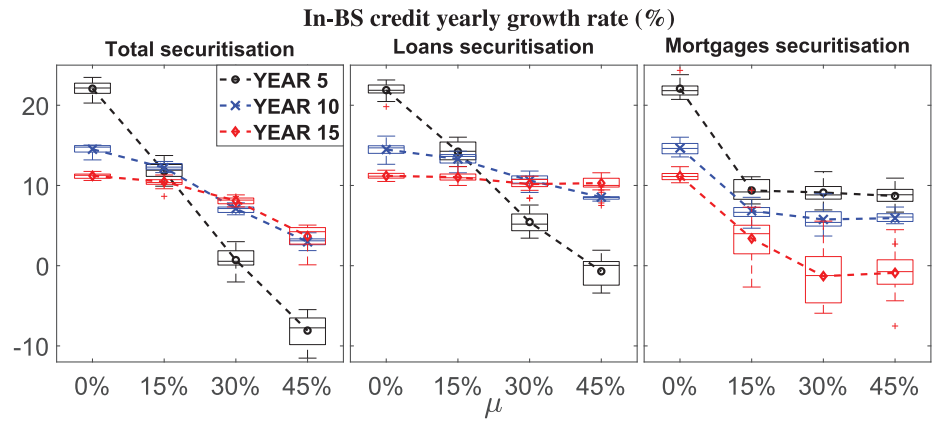

Figure 8. Boxplots and means of in-BS credit yearly growth rate, for three different time spans $(5,10$, and 15 years), three typologies of securitization (TS, LS, and MS), and four values of $\mu(0,15 \%, 30 \%$, and $45 \%)$.

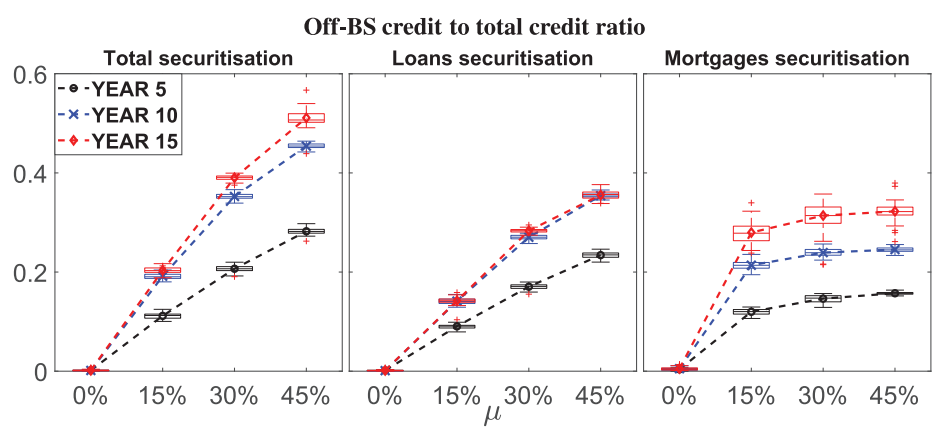

Figure 9. Boxplots and means of off-BS credit to total credit ratio, for three different time spans (5, 10, and 15 years), three typologies of securitization (TS, LS, and MS), and four values of $\mu(0 \%, 15 \%, 30 \%$, and $45 \%)$.
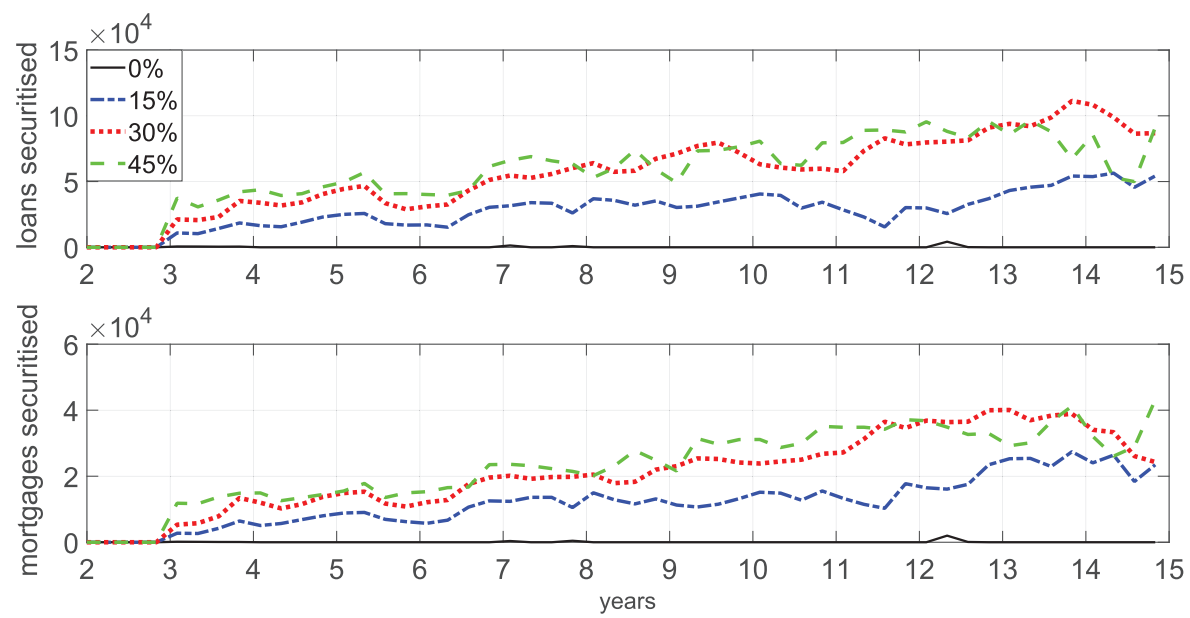

Figure 10. Quarterly securitized loans (top panel) and mortgages (bottom panel). Four values of $\mu$ are shown: $0 \%, 15 \%, 30 \%$, and $45 \%$.

securitized; thus their amount over the total credit does not reach the same level of TS, due to the different riskweights of loans and mortgages and to the possibility, especially in MB scenario, that the amount of mortgages in bank's balance sheet is not enough to fulfill the securitization requests, especially in the long run. Therefore, LS and MS scenarios represent a useful model's sensitivity exercise, but we mainly refer to TS scenario in the results, since it represents the most complete and realistic framework. 

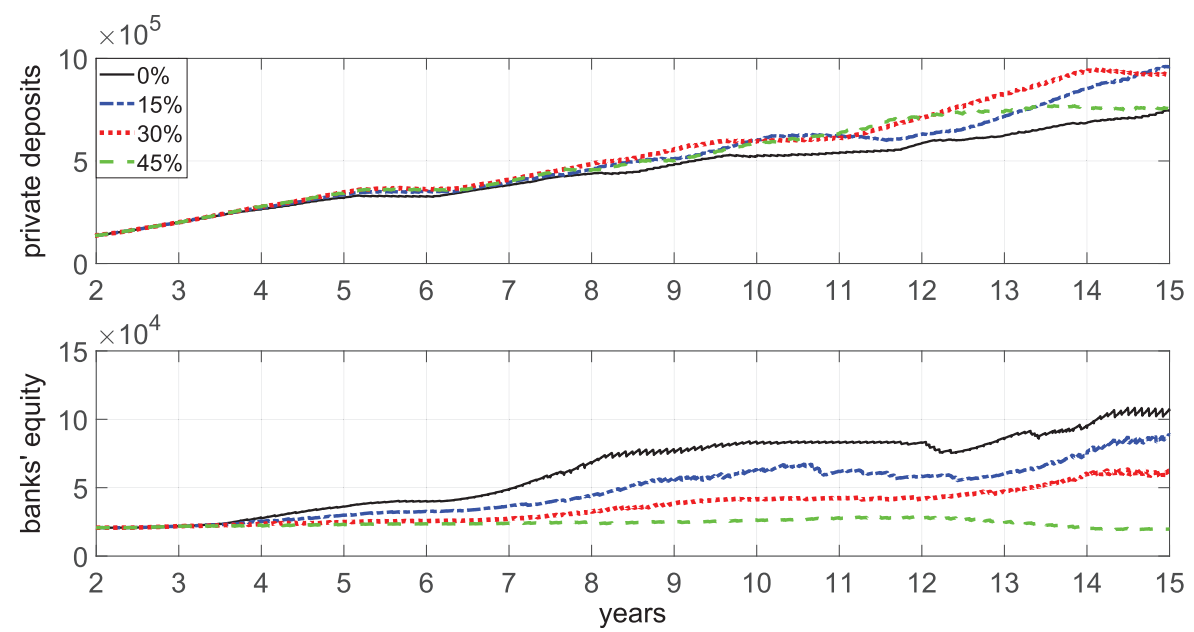

Figure 11. Private sector deposits (top panel) and banks' equity level (bottom panel). Four values of $\mu$ are shown: $0 \%, 15 \%, 30 \%$, and $45 \%$.

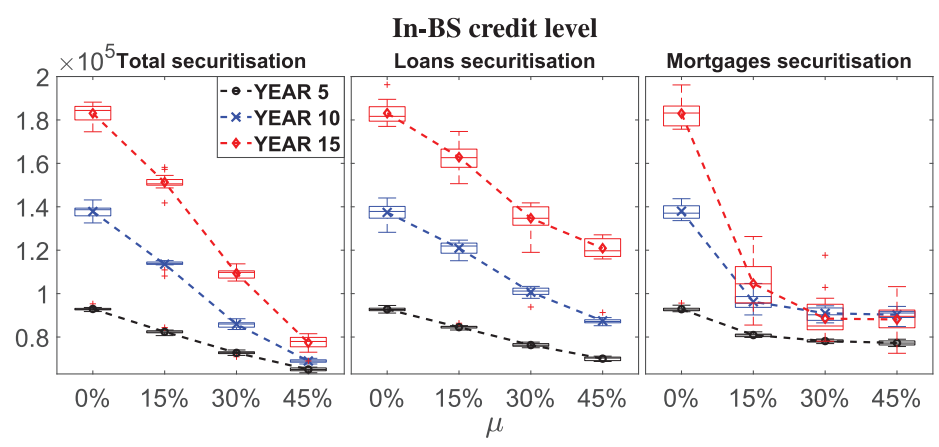

Figure 12. Boxplots and means of in-BS credit level, for three different time spans $(5,10$, and 15 years), three typologies of securitization (TS, LS, and MS), and four values of $\mu(0 \%, 15 \%, 30 \%$, and $45 \%)$.

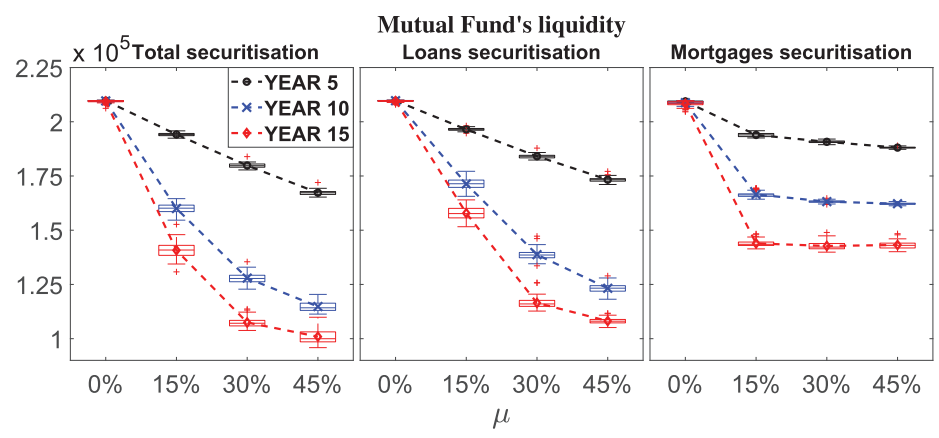

Figure 13. Boxplots and means of the mutual fund's liquidity, for three different time span $(5,10$, and 15 years $)$, three typologies of securitization (TS, LS, and MS), and four values of $\mu(0 \%, 15 \%, 30 \%$, and $45 \%)$.

The amount of off-BS credit has a direct impact on banks' regulatory capital. Regulatory capital refers to the capital that banks must hold because of regulatory requirements. In our setting, the value of $k$ is $10 \%$, where $k$ represent the capital adequacy ratio (see equations (5) and (6)). This entails that the ratio between equity and risk-weighted assets shall be at least $10 \%$, i.e., banks can lend an amount of credit (weighted for the risk) equivalent to maximum 


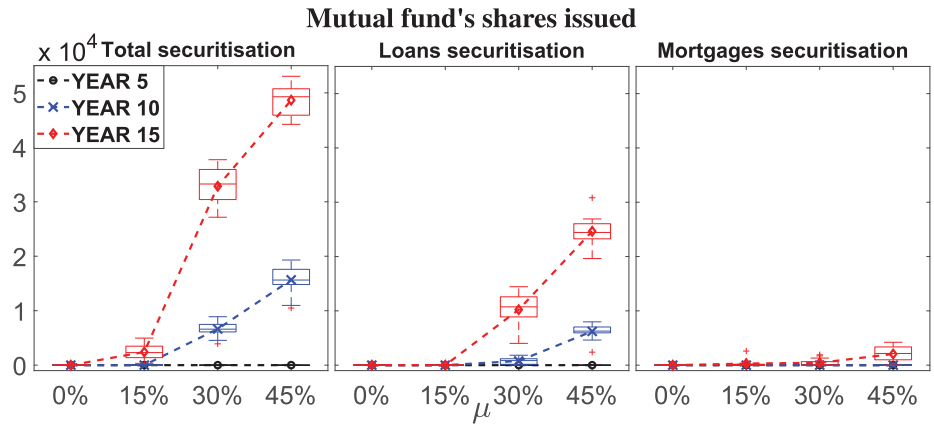

Figure 14. Boxplots and means of the mutual fund's share issued, for three different time span (5, 10, and 15 years), three typologies of securitization (TS, LS, and MS), and four values of $\mu(0 \%, 15 \%, 30 \%$, and $45 \%)$.

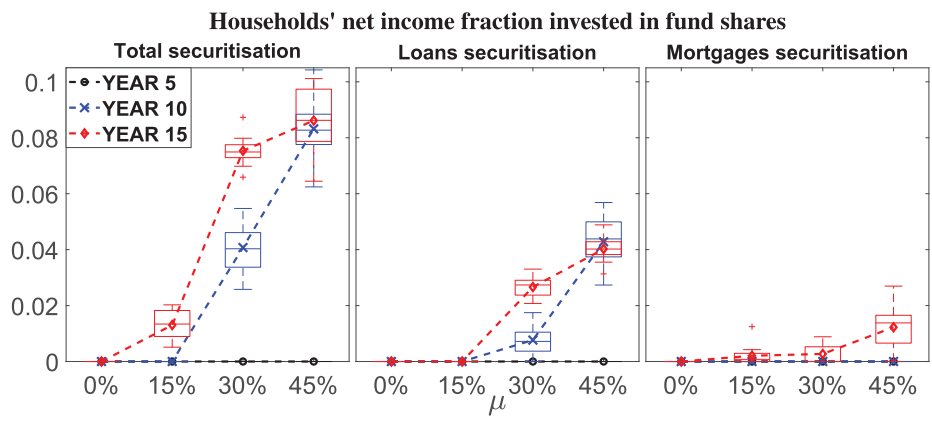

Figure 15. Boxplots and means of the fraction of households' net income invested in mutual fund's shares, for three different time $\operatorname{span}_{\perp}(5,10$, and 15 years), three typologies of securitization (TS, LS, and MS), and four values of $\mu(0 \%, 15 \%, 30 \%$, and $45 \%)$.

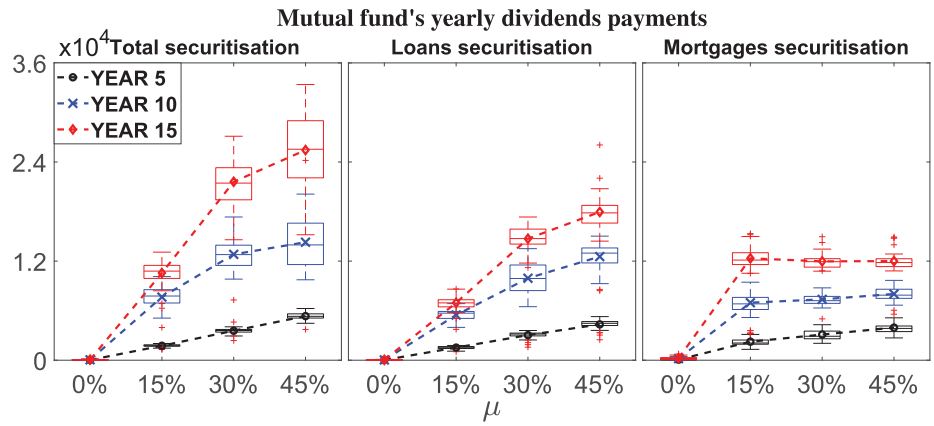

Figure 16. Boxplots and means of the mutual fund's yearly dividends'- payment, for three different time span $(5,10$, and 15 years), three typologies of securitization (TS, LS, and MS), and four values of $\mu(0 \%, 15 \%, 30 \%$, and $45 \%)$.

10 times their equity, that results in a value of $\alpha$ equal to 10 in equations (5) and (6), being $\alpha=1 / k$. In our results, we do not show the ratio between equity and risk-weighted assets, but the ratio between equity and credit (not weighted for the risk), to have a more intuitive measurement.

Time series in Figure 18 show the ratio between banks' equity and in-BS credit as well as the ratio between banks' equity and the total credit. All scenarios present an equity to in-BS credit ratio equal or higher than the ratio between equity and total credit. This is straightforward since total credit is the sum of in-BS and off-BS credit. It is worth 


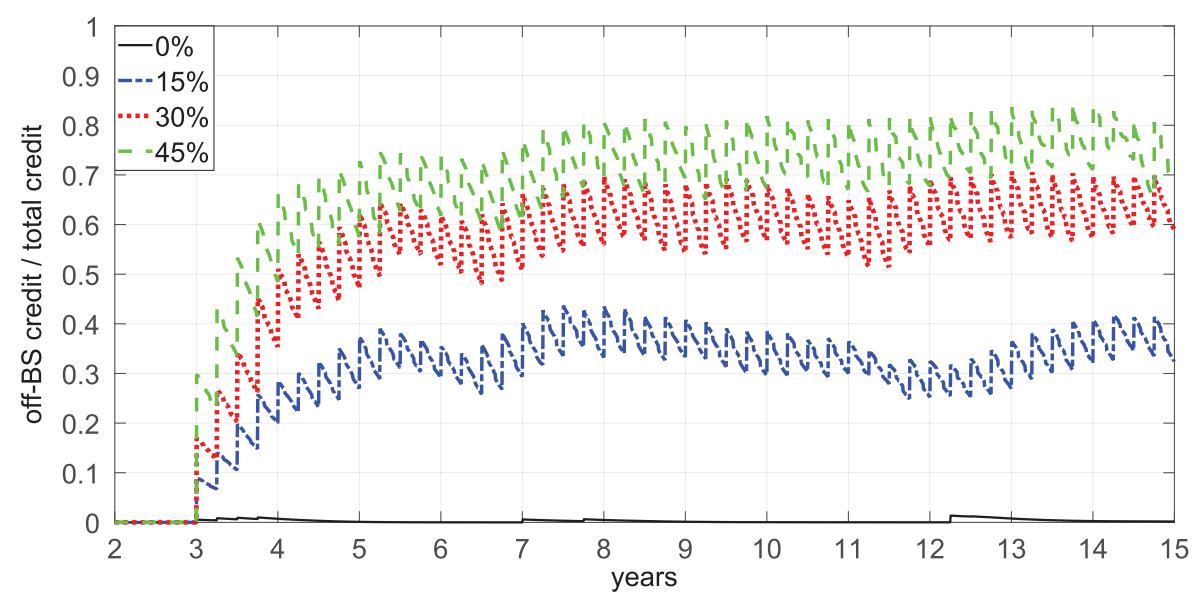

Figure 17. Off-BS credit to total credit ratio. Four values of $\mu$ are shown: $0 \%, 15 \%, 30 \%$, and $45 \%$.
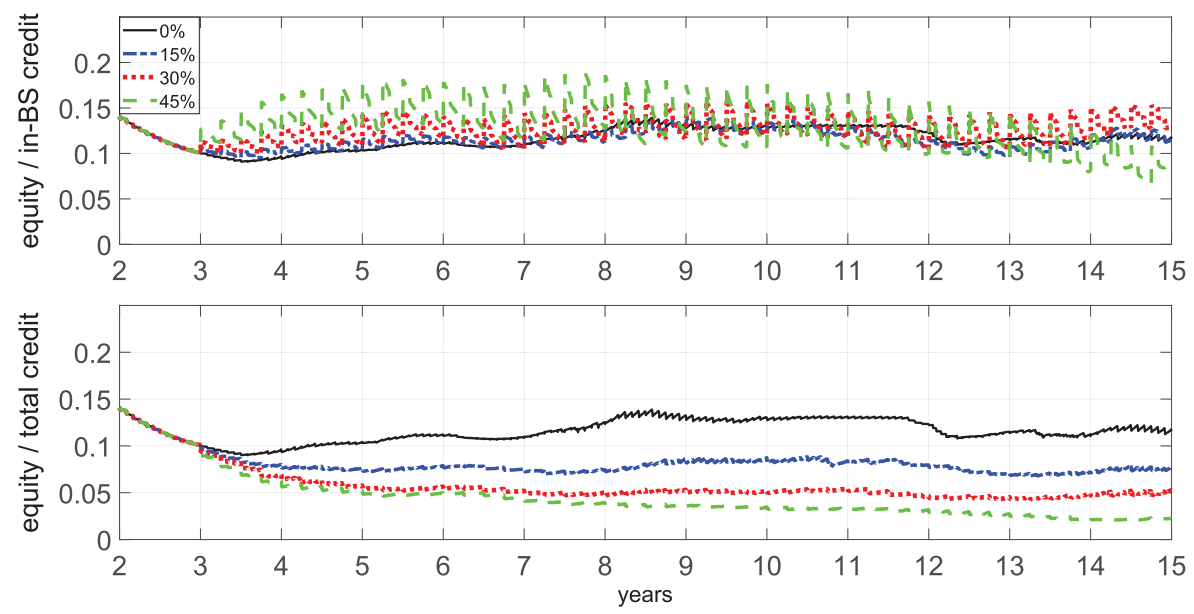

Figure 18. Equity to in-BS credit ratio (top panel) and equity to total credit ratio (bottom panel). Four values of $\mu$ are shown: $0 \%$, $15 \%, 30 \%$, and $45 \%$.

noting that, with the securitization enabled, even if banks formally satisfy the regulatory requirements, the systemic risk exposure of the economy is different.

In fact, time series in Figure 18 highlight that the equity to total credit ratio far exceeds the limits that banks should be subject to. This means that the regulatory capital requirement works (see boxplots in Figure 6), but banks, through securitization, are able to avoid the requirements and increase the credit in the economy, consequently arising the probability of bankruptcies and the systemic risk. Boxplots in Figures 6 and 19 give more information regarding different scenarios. Even if the ratio computed in Figure 6 has different values for TS, LS, and MS settings, given by different behavior of equity and credit, it is important to notice that the ratio is higher than 0.1 , except from the scenario with $\mu=45 \%$ at Year 15, due to a large number of bankruptcies that impact banks' equity (see boxplots in Figure 20). In this specific case, the aggressive securitization strategy creates deep financial crises with real economic effects, measured by the high number of firms' bankruptcies. In turn, firms' bankruptcies erode banks' assets and equity, pushing their capital level under the regulatory requirement. Boxplots in Figure 19, instead, show that the real risk exposure of the economy, measured as the ratio between banks' equity and total credit, exceeds the one allowed by regulatory capital requirement in a more consistent way for higher lever of $\mu$ and higher time spans. Our 


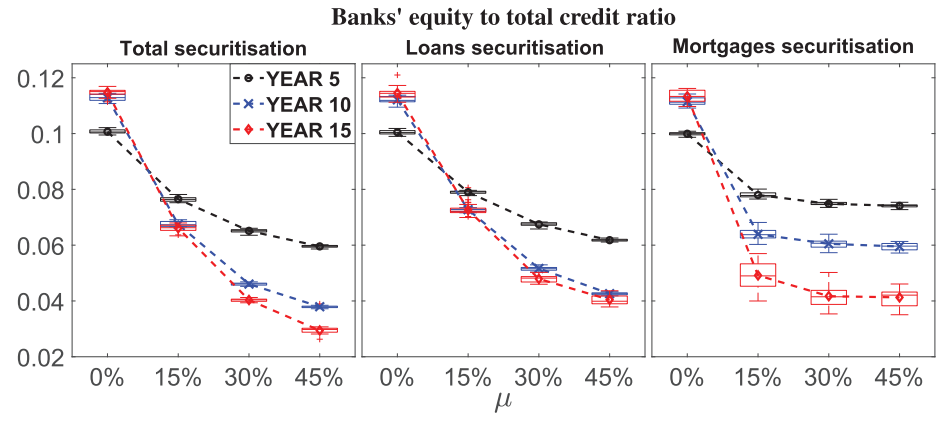

Figure 19. Boxplots and means of banks' equity to total credit ratio, for three different time spans $(5,10$, and 15 years), three typologies of securitization (TS, LS, and MS), and four values of $\mu(0 \%, 15 \%, 30 \%$, and $45 \%)$.

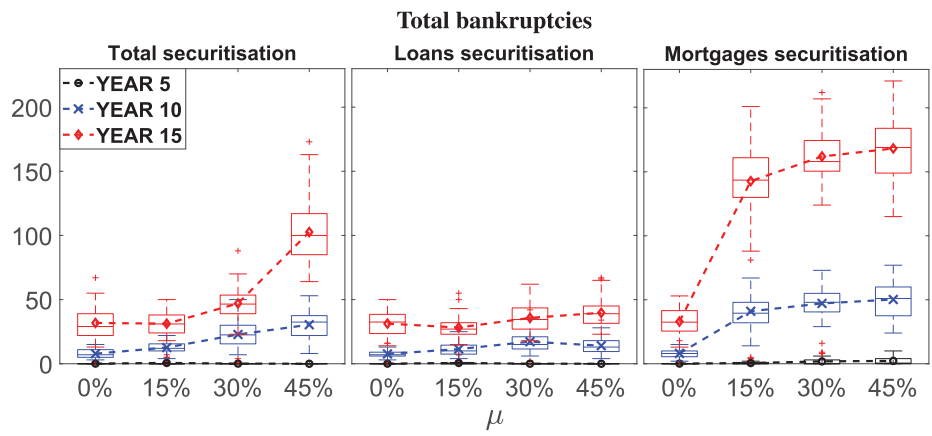

Figure 20. Boxplots and means of bankruptcies, for three different time spans $(5,10$, and 15 years), three typologies of securitization (TS, LS, and MS), and four values of $\mu(0 \%, 15 \%, 30 \%$, and $45 \%)$.

results show that banks can use securitization for regulatory capital arbitrage, to create more credit. The use of securitization to avoid regulatory capital requirements is supported by the literature (Ambrose et al., 2005; Efing, 2015; Gimenez Roche and Lermyte, 2016). Moreover, the reduction of regulatory capital requirements on capital and the consequent capacity of banks to supply new loans can change according to business cycle condition, as we show in the following subsections.

\subsection{Credit cycle}

Boxplots in Figures 3-5 show the growth rates of loans, mortgages, and total credit, respectively. We analyzed three time horizons, i.e., from Year 3 until the end of Years 5, 10, and 15 that we consider as short-run, medium-run, and long-run time periods. Boxplots indicate that loans, mortgages, and credit increase more consistently for high values of $\mu$ in the short run. In the medium and long run, this is not true for $\mu=30 \% \mu=45 \%$ scenario. Boxplots in Figure 5 confirm that at Years 10 and 15, the growth rate of total credit is higher only for $\mu=15 \%$, while too much securitization, i.e., $\mu=30 \% \mu=45 \%$, leads to a lower growth rate's average at Year-15 time span. Looking at Year5 analysis, TS setting shows higher credit growth rates for increasing values of $\mu$. Considering that at Year- 5 time span, business cycle is facing an expansion phase (see boxplots in Figures 21-23) without bankruptcies (see boxplot in Figure 20), we observe that securitization improves the economy through the higher amount of loans and mortgages lent by banks, during positive business cycle's stage. LS and MS settings also are characterized by higher growth rates for increasing level of securitization but do not reach the level of TS.

Moreover, LS scenario shows higher growth rates compared to MS. We argue that the main reason is due to the different risk weight assigned to CGPs loans and household mortgages. As pointed out in Section 4.2, banks compute the amount of credit to securitize according to the risk-weighted assets that they want to remove from their balance 


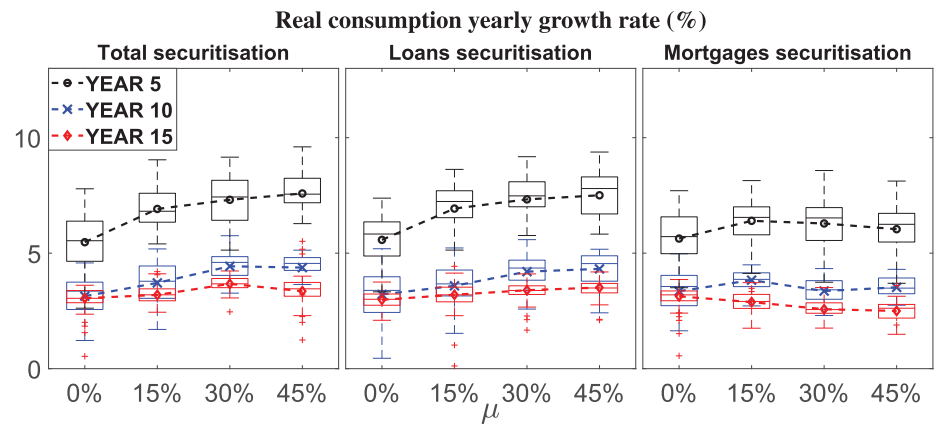

Figure 21. Boxplots and means of real consumption yearly growth rate, for three different time spans $(5,10$, and 15 years), three typologies of securitization (TS, LS, and MS), and four values of $\mu(0 \%, 15 \%, 30 \%$, and $45 \%)$.

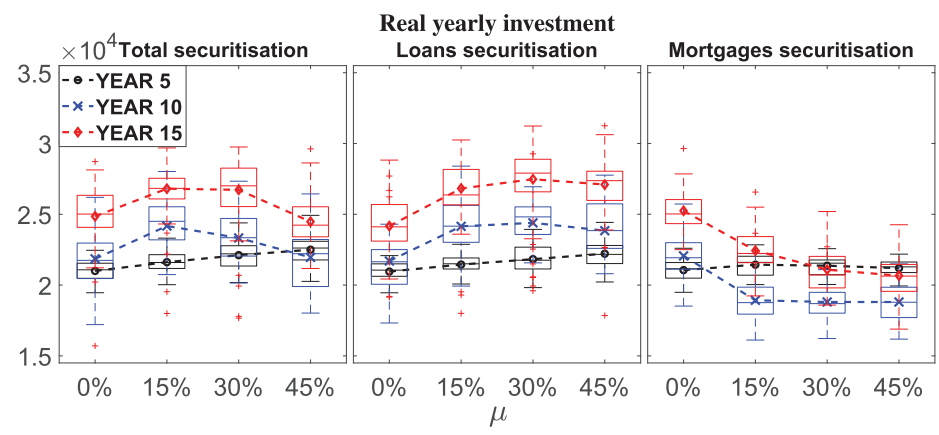

Figure 22. Boxplots and means of real investment, for three different time spans $(5,10$, and 15 years), three typologies of securitization (TS, LS, and MS), and four values of $\mu(0 \%, 15 \%, 30 \%$, and $45 \%)$.

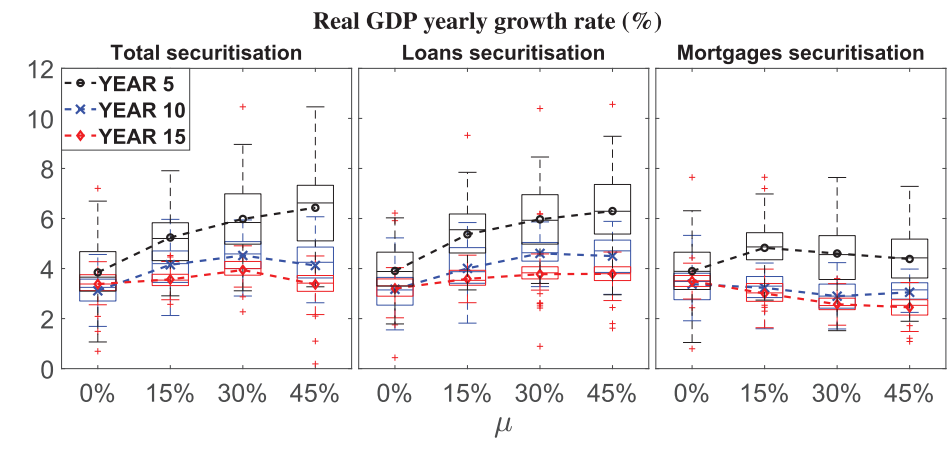

Figure 23. Boxplots and means of real GDP yearly growth rate, for three different time spans $(5,10$, and 15 years $)$, three typolog $y_{\perp}$ of securitization (TS, LS, and MS), and four values of $\mu(0 \%, 15 \%, 30 \%$, and $45 \%)$.

sheet. They compute the risk weight of new loans taking into account the balance sheet's debt and equity of CGPs (see equation (4)), while risk-weighted mortgages are computed as the half of the mortgages value. Being the risk weight of loans usually higher than 0.5 , mortgages to be securitized in the MS setting may be higher than loans in the LS one. This is relevant because there is a limit on the securitization volume, given by the amount of credit in bank's balance sheet. In particular, applying the share of securitization only on loans or mortgages may have the effect that banks could not securitize the amount required because not endowed with a sufficient amount of loans or mortgages. The consequence is that, in the long run, banks have lower possibility to lend due to Basel II/III regulation and no possibility to securitize. The effect is a credit crunch and a high number of illiquidity bankruptcies. 


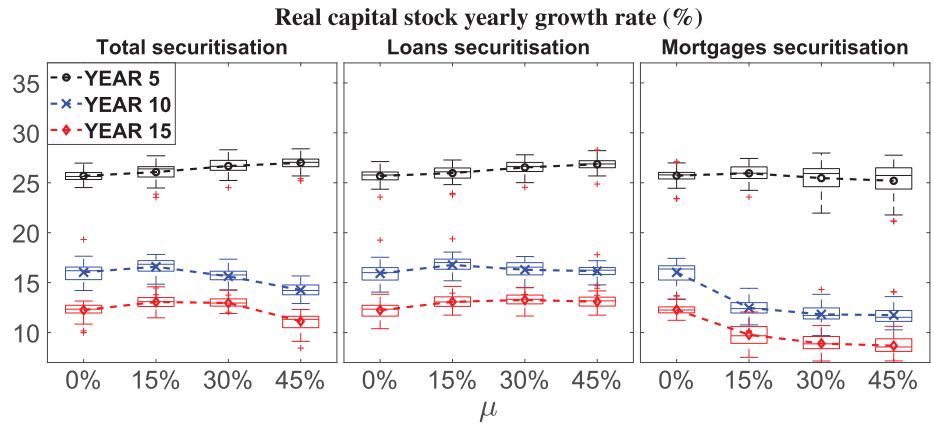

Figure 24. Boxplots and means of capital stock yearly growth rate, for three different time spans (5, 10, and 15 years), three typologies of securitization (TS, LS, and MS), and four values of $\mu(0 \%, 15 \%, 30 \%$, and $45 \%)$.

In this work we do not focus on the effects of securitization on the housing market and on the demand of ABSs and MBSs. We want to show the effects of different securitization settings on banks' balance sheet. In this respect, MS and LS differ only in terms of amount of securitized assets. This amount can be relevant because, given the same value $S_{b}$, mortgages to be securitized in MS are usually higher than the loans in LS, for the reason explained above. In both cases, banks increase less their equity (according to $\mu$ ) when securitization mechanism starts, because they use the channel of FVC to lend more (see boxplots in Figure 2). But in the TS and LS settings, banks can bear this situation because they keep using securitization channel, increasing the amount of off-BS credit, as shown in boxplots in Figure 9. In the MS case, instead, banks cannot securitize as much as they need because it is possible that there are not enough mortgages in bank's balance sheet, especially in the medium and long run. This leads a higher number of bankruptcies (boxplots in Figure 20) and worst economic performances (boxplots in Figures 21-24). Therefore, as stated before, we mainly refer to TS scenario in the explanation of results, since it better assess the complete and more realistic case that securitization involves both loans and mortgages.

Furthermore, we refer to bankruptcies only for CGPs, as we have not considered a resolution mechanism in case of bank's bankruptcy. This is not a limitation for our analysis, since negative bank's equity simply results in a credit freeze, while bank tries to rise its equity. A resolution mechanism would burden on taxpayers and depositors, thus reinforcing the negative economic spiral that we observe in case of high securitization propensity and confirming our results. Anyhow, boxplots in Figure 2 show that banks' equity on average is positive across our simulations.

\subsection{Business cycle}

Eurace model is able to reproduce endogenous business cycles and endogenous crises; see for instance Raberto et al. (2012). Time series in Figure 25 show real consumption, real investment, and bankruptcies, while time series in Figure 26 show the central bank policy rate and the inflation rate. Real consumption and investment are characterized by a growth trend in the long run and recessions of different intensity followed by recoveries. The longrun growth is only triggered by capital accumulation (see boxplots in Figure 24), since firms are endowed with an initial amount of physical capital that can be increased. Changes in technology and increase of population are not considered in this work, and we focus on the short-run out-of-equilibrium dynamics.

Therefore, we are interested in studying the role of securitization mechanism in affecting the short-term economic performance and financial stability. However, medium- and long-run time spans (Years 10 and 15) include a longer sequence of business cycles, and securitization may affect their length and amplitude.

To assess in an objective way the effects of different securitization propensities' scenarios on business cycles, we measure recessions and expansions, for three securitization type scenarios (i.e., "Total securitization," "Loans securitization," and "Mortgages securitisation") and four securitization propensities ( $\mu=0 \%, 15 \%, 30 \%$, and $45 \%$ ) across 50 seeds and Year-15 time span. Recession is defined as 2 (or more) consecutive months of negative GDP growth rate, while expansion is represented as 2 (or more) consecutive months of positive GDP growth rate. We study those recessions and expansions in terms of quantity (\# Recessions), i.e., the number of times that two or more consecutive GDP negative or positive growth occurs, duration (\# months), given by the mean of the number of 


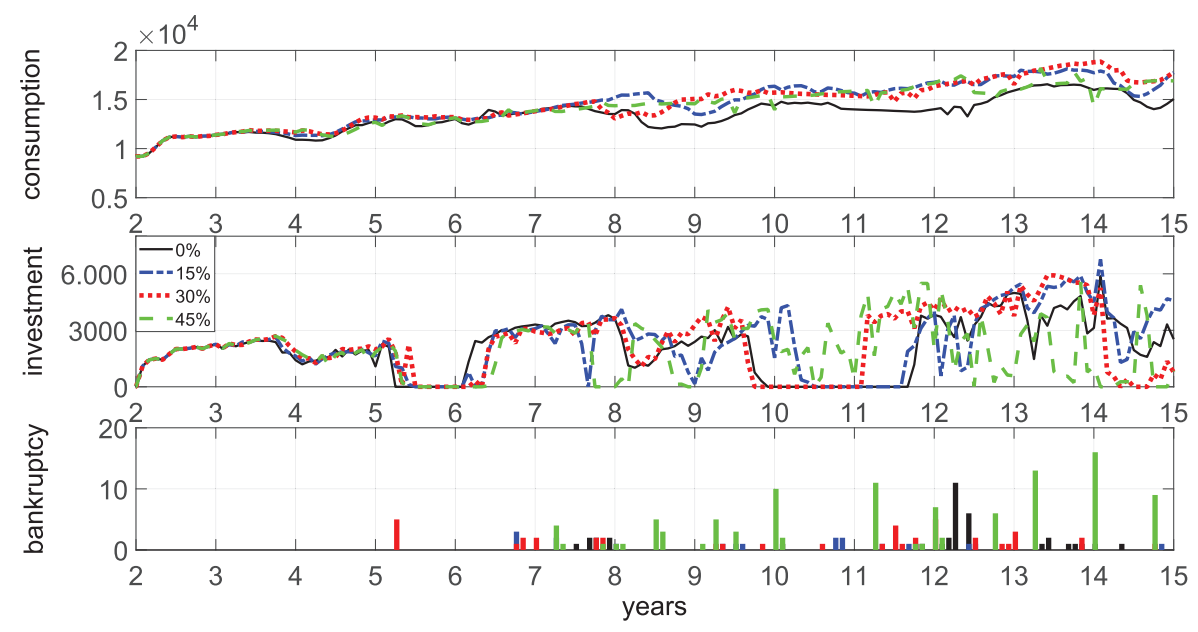

Figure 25. Real consumption level (top panel), real investments (middle panel), and number of bankruptcies (bottom panel). Four values of $\mu$ are shown: $0 \%, 15 \%, 30 \%$, and $45 \%$.
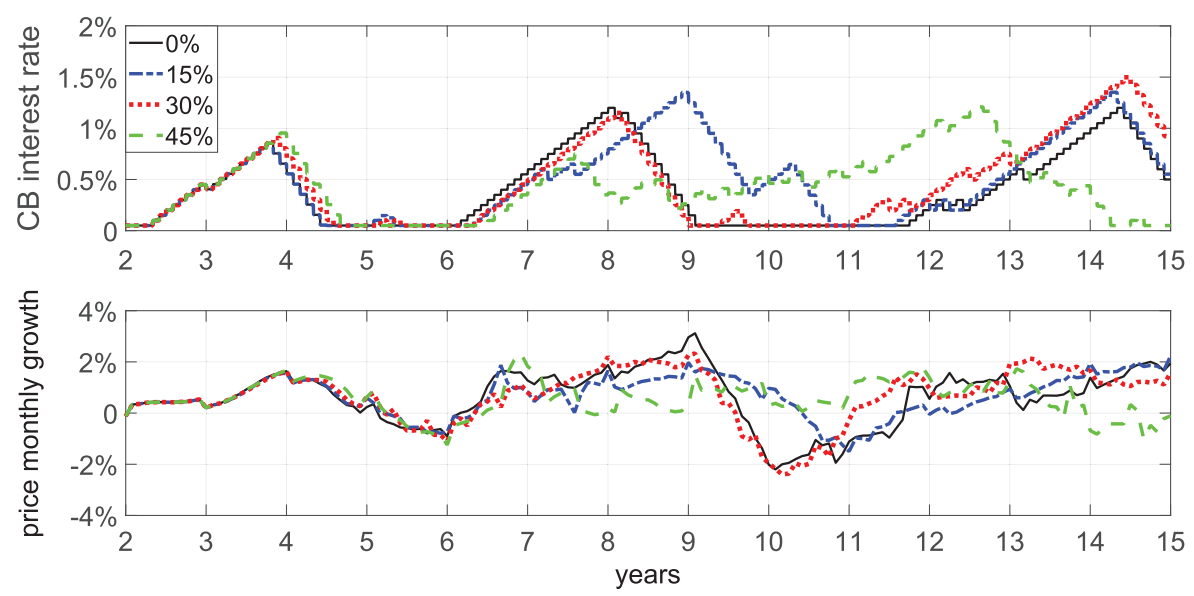

Figure 26. CB policy rate (top panel) and inflation (bottom panel). Four values of $\mu$ are shown: $0 \%, 15 \%, 30 \%$, and $45 \%$.

consecutive months in which GDP growth is negative or positive, and severity (GDP fall or growth (\%)), measured as the mean of the GDP decrease or increase, during recessions or expansions. In this way, we can compare how different scenarios impact on different phases of business cycles. Results of Tables 6 and 7 highlight that an increase in the securitization propensity entails not only an higher number of recessions but also stronger downturns, with GDP decrease that reach $5 \%$ or even $6 \%$ in extreme scenarios. However, the duration is decreasing for higher values of $\mu$. This is due to the fact that our definition of recession considers at least two consecutive months of negative GDP; therefore, the higher number of recessions increases the probability to face shorter downturns. Regarding expansions, Table 7 highlights that, despite some differences among credit quality scenarios, increasing values of $\mu$ are linked with higher expansion phases, suggesting that securitization mechanism has an amplification effect on the business cycle, since it triggers higher expansions and deeper recessions.

It is worth noting that the impact of securitization to the business cycle is mainly twofold:

- Through the credit cycle, securitization affects the amount of loans and mortgages lent to the CGPs and households, influencing investment and consumption. 
Table 6. Analysis of recessions, defined as two or more consecutive months of negative GDP

\begin{tabular}{llll}
\hline$\mu$ & \# Recessions & \# Months & GDP fall (\%) \\
\hline TS $(\%)$ & & & $-3.1(0.1)$ \\
0 & $12.6(0.1)$ & $4.0(0.1)$ & $-3.3(0.1)$ \\
15 & $12.8(0.1)$ & $3.6(0.1)$ & $-3.7(0.1)$ \\
30 & $15.1(0.1)$ & $3.3(0.1)$ & $-5.8(0.1)$ \\
45 & $15.7(0.1)$ & $2.9(0.1)$ & $-3.3(0.1)$ \\
LS $(\%)$ & & & $-3.1(0.1)$ \\
0 & $12.8(0.1)$ & $3.9(0.1)$ & $-3.3(0.1)$ \\
15 & $12.9(0.1)$ & $3.8(0.2)$ & $-3.6(0.1)$ \\
30 & $13.3(0.1)$ & $3.4(0.1)$ & $-3.3(0.1)$ \\
45 & $13.5(0.1)$ & $3.7(0.2)$ & $-6.6(0.1)$ \\
MS $(\%)$ & & & $-6.2(0.1)$ \\
0 & $12.5(0.1)$ & $3.9(0.1)$ & $-6.1(0.2)$ \\
15 & $16.8(0.2)$ & $2.7(0.1)$ & $2.9(0.1)$ \\
30 & $16.8(0.1)$ & $2.8(0.2)$ & \\
45 & $18.0(0.2)$ & & \\
\hline
\end{tabular}

Note: Standard errors in parentheses.

Table 7. Analysis of expansions, defined as two or more consecutive months of positive GDP growth

\begin{tabular}{llll}
\hline$\mu$ & \# Expansions & \# months & GDP growth (\%) \\
\hline TS $(\%)$ & & & \\
0 & $19.6(0.1)$ & $4.9(0.1)$ & $3.0(0.1)$ \\
15 & $20.3(0.1)$ & $4.8(0.1)$ & $3.0(0.1)$ \\
30 & $21.5(0.1)$ & $4.3(0.1)$ & $3.5(0.1)$ \\
45 & $23.0(0.2)$ & $4.0(0.1)$ & $4.7(0.1)$ \\
LS $(\%)$ & & & $3.1(0.1)$ \\
0 & $19.6(0.1)$ & $5.0(0.1)$ & $2.9(0.1)$ \\
15 & $19.8(0.1)$ & $4.9(0.1)$ & $3.1(0.1)$ \\
30 & $20.8(0.1)$ & $4.7(0.1)$ & $3.4(0.1)$ \\
45 & $20.8(0.1)$ & $4.6(0.1)$ & $3.1(0.1)$ \\
MS $(\%)$ & & & $4.8(0.1)$ \\
0 & $19.6(0.1)$ & $4.9(0.1)$ & $4.9(0.1)$ \\
15 & $22.6(0.1)$ & $4.2(0.1)$ & $4.9(0.1)$ \\
30 & $21.6(0.1)$ & $4.2(0.1)$ & $4.2(0.2)$ \\
45 & $21.6(0.1)$ & & \\
\hline
\end{tabular}

Note: Standard errors in parentheses.

- Through banks' and mutual fund's dividends paid to households, increasing their capital income.

Boxplots in Figures 20-24 show the main economic outputs for three time spans and three different settings: TS, LS, and MS. TS scenario shows that in the short run, real investment level, real consumption, and real GDP yearly growth rates increase for higher values of securitization propensity $\mu$. However, Year- 5 time span is characterized by an expansion phase of the business cycle. Results are different in the medium and long run, since the systemic risk arised by the increased amount of credit lent triggers more bankruptcies that hit banks' equity and their lending activity, resulting in more severe downturns, especially when securitization propensity $\mu$ is high. According to computational experiments, the best economic performances are achieved by the setting with $\mu=15 \%$. A low level of securitization is the best compromise between economic activity and financial fragility.

The presented results highlight the relevance of securitization process for the business cycle and the possible effects of securitization on the real economy, in line with other studies on this topic. For instance, Altunbas et al. (2009) 
show how banks increase their lending activity using securitization for regulatory capital arbitrage and point out, using empirical analysis, that this effect is maximized during economic expansions. We show this aspect since, in our results, the credit expansion is higher across the Year-5 time span, where business cycle is facing an expansion phase. Moreover, we show that during economic downturns securitization impacts negatively the business cycle, especially for high values of securitization propensity. Also Peersman and Wagner (2015) analyze lending, securitization, and risk-taking shocks and find that securitization has relevant effects on US business cycle. Furthermore, Bertay et al. (2016) show the credit composition channel of securitization, stating that countries with more securitization on business loans have higher economic growth, as opposed to household mortgages. Although we focus on the credit volume channel, we find that securitization can result in more investments and thus trigger economic activity.

In addition to the related literature, we observe that securitization can have positive or negative effects on business cycle, depending on the securitization propensity and economic conditions. If securitization propensity is low, it can help lending activity without overly exposing the economy, resulting in less severe economic recessions. An increase in the securitization propensity, instead, amplifies the economic performance during growing periods but leads to deeper economic downturns.

\section{Concluding remarks}

This work focuses on the study of securitization impact on credit and business cycles using an agent-based stock-flow consistent model. For this purpose, Eurace agent-based macroeconomic simulator has been enhanced with the addition of the securitization mechanism and new agents, namely, FVC and mutual fund.

Through securitization, banks are able to sell loans and mortgages to FVC, which pools them and issues ABSs and MBSs, sold to the mutual fund, which can issue shares to finance its activity. A securitization propensity $(\mu)$ has been introduced to study the effects of different degrees of securitization. Quarterly, depending on its value, banks determine the amount of risk-weighted assets to securitize. Securitization mechanism impacts the structure of banks' balance sheet and influences the credit cycle, due to the banks' ability to overcome Basel II/III capital requirements.

Computational experiments' results show that in the short run, securitization triggers a boom to the growth but increases significantly the fragility of the economy in the long run. The best economic performance in the short run is given by the highest values of $\mu$. This is not confirmed in a time span of 10 years, where scenarios with the highest $\mu$ are affected negatively by the fragility of the banking sector. In the long run, the best scenario is given by $\mu=15 \%$, which also shows better results for all simulations' time spans compared to the baseline scenario $(\mu=0 \%)$, suggesting that a restrained securitization can be a benefit for the economy. Higher levels of securitization propensity, instead, cause severe crises in the long run due to the increased financial fragility given by banks' excessive use of securitization, leading to bankruptcies of CGPs and households' capital income reductions.

\section{Acknowledgment}

The authors acknowledge EU-FP7 collaborative project SYMPHONY ${ }^{9}$ under the grant number 611875.

\section{References}

Acharya, V. V., P. Schnabl and G. Suarez (2013), 'Securitization without risk transfer,' Journal of Financial Economics, 107(3), 515-536.

Adrian, T. and H. S. Shin (2010), 'The changing nature of financial intermediation and the financial crisis of 2007-2009,' Annual Review of Economics, 2(1), 603-618.

Altunbas, Y., L. Gambacorta and D. Marques-Ibanez (2009), 'Securitisation and the bank lending channel,' European Economic Review, 53(8), 996-1009.

Ambrose, B. W., M. LaCour-Little and A. B. Sanders (2005), 'Does regulatory capital arbitrage, reputation, or asymmetric information drive securitization?,' Journal of Financial Services Research, 28(1-3), 113-133.

Assenza, T., D. Delli Gatti and J. Grazzini (2015), 'Emergent dynamics of a macroeconomic agent based model with capital and credit,' Journal of Economic Dynamics and Control, 50, 5-28. 
Bertay, A. C., D. Gong and W. Wagner (2016), 'Securitization and economic activity: the credit composition channel,' Journal of Financial Stability, 28, 225-239.

Bhaduri, A., S. Raghavendra and V. Guttal (2015), 'On the systemic fragility of finance-led growth,' Metroeconomica, 66(1), 158-186.

BoE and ECB (2014), 'The case for a better functioning securitisation market in the European Union,' Discussion Paper.

Botta, A., E. Caverzasi and D. Tori (2016), 'The macroeconomics of shadow banking,' Working Paper 1161, Greenwich Papers in Political Economy.

Brunnermeier, M. K. and Y. Sannikov (2014), 'A macroeconomic model with a financial sector,' American Economic Review, 104(2), 379-421.

Caiani, A., A. Godin, E. Caverzasi, M. Gallegati, S. Kinsella and J. Stiglitz (2016), 'Agent based-stock flow consistent macroeconomics: towards a benchmark model,' Journal of Economic Dynamics and Control, 69 (C), 375-408.

Cappiello, L., A. Kadareja, C. Kok and M. Protopapa (2010), 'Do bank loans and credit standards have an effect on output? A panel approach for the euro area,' Working Paper Series 1150, European Central Bank.

Carroll, C. D. (2001), 'A theory of the consumption function, with and without liquidity constraints,' Journal of Economic Perspectives, 15(3), 23-45.

Caverzasi, E. and A. Godin (2015), 'Post-keynesian stock-flow-consistent modelling: a survey,' Cambridge Journal of Economics, (157-187.

C = , G. (2008), 'Optimal credit risk transfer, monitored finance, and banks,' Journal of Financial Intermediation, 17(4), 464-477.

Cincotti, S., M. Raberto and A. Teglio (2012a), 'The Eurace macroeconomic model and simulator. In: agent-based Dynamics, Norms, and Corporate Governance,' in The proceedings of the 16-th World Congress of the International Economic Association,' Vol. II, Palgrave.

Cincotti, S., M. Raberto and A. Teglio (2012b), 'Macroprudential policies in an agent-based artificial economy, Agents and Economy Policy, 124(5), 205-234.

Dawid, H., S. Gemkow, P. Harting, S. van der Hoog and M. Neugart (2018), Agent-Based Macroeconomic Modeling and Policy Analysis: The Eurace@Unibi Model. Oxford University Press: Oxford, pp. 490-519.

Deaton, A. (1992), 'Household saving in ldcs: credit markets, insurance and welfare,' The Scandinavian Journal of Economics, 94(2), 253-273.

DeMarzo, P. M. (2005), 'The pooling and tranching of securities: a model of informed intermediation,' Review of Financial Studies, 18(1), 1-35.

Demyanyk, Y. and O. Van Hemert (2011), 'Understanding the subprime mortgage crisis,' Review of Financial Studies, 24(6), 1848-1880.

Di Patti, E. B. and E. Sette (2016), 'Did the securitization market freeze affect bank lending during the financial crisis? evidence from a credit register,' Journal of Financial Intermediation, 25, 54-76.

Dosi, G., G. Fagiolo, M. Napoletano and A. Roventini (2013), 'Income distribution, credit and fiscal policies in an agent-based Keynesian model,' Journal of Economic Dynamics \& Control, 37(8), 1598-1625.

Dosi, G., G. Fagiolo and A. Roventini (2010), 'Schumpeter meeting Keynes: a policy-friendly model of endogenous growth and business cycles,' Journal of Economic Dynamics and Control, 34(9), 1748-1767.

Dosi, G., M. Napoletano, A. Roventini and T. Treibich. January (2017), 'Micro and macro policies in the Keynes+Schumpeter evolutionary models,' Journal of Evolutionary Economics, 27(1), 63-90.

Efing, M. (2015), 'Arbitraging the Basel Securitization Framework: Evidence from German Abs Investment,' Discussion Papers 40/2015, Deutsche Bundesbank, Research Centre.

Erlingsson, E., A. Teglio, S. Cincotti, H. Stefansson, J. Sturluson and M. Raberto (2014), 'Housing market bubbles and business cycles in an agent-based credit economy,' Economics: The Open-Access, Open-Assessment E-Journal, 8(2014-8), 1-42.

Fabiani, S., M. Druant, I. Hernando, C. Kwapil, B. Landau, C. Loupias, F. Martins, T. Mathä, R. Sabbatini, H. Stahl and A. Stokman (2006), 'What firms' surveys tell us about price-setting behavior in the euro area,' International Journal of Central Banking, 2(3), $3-47$.

Fagiolo, G. and A. Roventini (2017), 'Macroeconomic policy in DSGE and agent-based models redux: new developments and challenges ahead,' Journal of Artificial Societies and Social Simulation, 20(1), 3280.

Fazzari, S. M., P. Ferri and E. Greenberg (2008), 'Cash flow, investment, and Keynes-Minsky cycles,' Journal of Economic Behavior and Organization, 65(3-4), 555-572.

Fontana, O. and A. Godin (2013), 'Securitization, housing market and banking sector behavior in a stock-flow consistent model,' Economics Discussion Paper 2013-13, Kiel Institute for the World Economy.

FSB (2011), 'Shadow Banking - strengthening oversight and regulation: recommendations of the financial stability board,' Financial Stability Board, 1(2), 247.

Fujii, M. (2012), 'Securitized products, financial regulation and systemic risk,' in Implications of the Global Financial Crisis for Financial Reform and Regulation in Asia. Edward Elgar Publishing: Cheltenham, Ch. 5. 
Gimenez Roche, G. and J. Lermyte (2016), 'Securitization and regulatory arbitrage within the ABCT framework,' The Review of Austrian Economics, 29(1), 67-84.

Godley, W. and M. Lavoie (2012), Monetary Economics: An Integrated Approach to Credit, Money, Income, Production and Wealth, 2nd edn. Palgrave Macmillan: Basingstoke.

Gorton, G. and A. Metrick (2010), 'Regulating the shadow banking system,' Brookings Papers on Economic Activity, 2010(2), 261-312.

Gorton, G. and A. Metrick (2012), 'Securitized banking and the run on repo,' Journal of Financial Economics, 104(3), $425-451$.

Gorton, G. B. and G. Ordonez (2013), 'The supply and demand for safe assets,' Working Paper 18732, National Bureau of Economic Research.

Graham, J. and C. Harvey (2001), 'The theory and practice of corporate finance: evidence from the field,' Journal of Financial Economics, 60(2-3), 187-243.

Graham, J. and C. Harvey (2002), 'How do CFOs make capital budgeting and capital structure decisions?,' Journal of Applied Corporate Finance, 15(1), 8-23.

Gualdi, S., M. Tarzia, F. Zamponi and J. Bouchaud (2015), 'Tipping points in macroeconomic agent-based models,' Journal of Economic Dynamics and Control, 50, 29-61.

Hillier, F. and G. Lieberman (1986), Introduction to Operations Research, 4th edn. Holden-Day Inc: San Francisco, CA.

Instefjord, N. (2005), 'Risk and hedging: do credit derivatives increase bank risk?,' Journal of Banking and Finance, 29(2), 333-345.

Jones, D. (2000), 'Emerging problems with the Basel capital accord: regulatory capital arbitrage and related issues,' Journal of Banking \& Finance, 24(1-2), 35-58.

Kahneman, D. and A. Tversky (1979), 'Prospect theory: an analysis of decision under risk,' Econometrica, 47(2), $263-292$.

Keys, B., T. Mukherjee, A. Seru and V. Vig (2010), 'Did securitization lead to lax screening? evidence from subprime loans,' The Quarterly Journal of Economics, 125(1), 307-362.

Klimek, P., S. Poledna, D. Farmer and S. Thurner (2015), 'To bail-out or to bail-in? answers from an agent-based model,' Journal of Economic Dynamics and Control, 50, 144-154.

Lillo, F. and D. Pirino (2015), 'The impact of systemic and illiquidity risk on financing with risky collateral,' Journal of Economic Dynamics and Control, 50, 180-202.

Loutskina, E. (2011), 'The role of securitization in bank liquidity and funding management,' Journal of Financial Economics, 100(3), 663-684.

Lysandrou, P. and A. Nesvetailova (2014), 'The role of shadow banking entities in the financial crisis: a disaggregated view,' Review of International Political Economy, 22(2), 257.

McLeay, M., A. Radia and R. Thomas (2014), 'Money creation in the modern economy,' Bank of England Quarterly Bulletin, 54(1), $14-27$.

Moreira, A. and A. Savov (2017), 'The macroeconomics of shadow banking,' The Journal of Finance, 72(6), $2381-2432$.

Myers, S. and N. Majluf (1984), 'Corporate financing and investment decisions when firms have information that investors do not have,' Journal of Financial Economics, 13(2), 187-221.

Napoletano, M., A. Roventini and S. Sapio (2006), 'Are business cycles all alike? A bandpass filter analysis of the Italian and us cycles,' Rivista Italiana Degli Economisti, 1, 87-118.

Nersisyan, Y. and L. R. Wray (2010), 'The global financial crisis and the shift to shadow banking,' Economics Working Paper Archive, Levy Economics Institute.

Nikolaidi, M. (2015), 'Securitization, wage stagnation and financial fragility: a stock-flow consistent perspective,' Greenwich Papers, Political Economy, n. 27.

Ozel, B., R. C. Nathanael, M. Raberto, A. Teglio and S. Cincotti (2016), 'Macroeconomic implications of mortgage loans requirements: an agent based approach,' Working Papers 2016/05, Economics Department, Universitat Jaume I, Castellón, Spain.

Peersman, G. and W. Wagner (2015), 'Shocks to bank lending, risk-taking, securitization, and their role for U.S. business cycle fluctuations,' CEPR Discussion Papers 10547, C.E.P.R. Discussion Papers.

Pennacchi, G. (1988), 'Loan sales and the cost of bank capital,' Rodney l. White Center for Financial Research Working Papers, Wharton School Rodney L. White Center for Financial Research.

Plantin, G. (2004), 'Tranching,' GSIA Working Papers 2005-E2, Carnegie Mellon University, Tepper School of Business.

Plott, C. R. and S. Sunder (1982), 'Efficiency of experimental security markets with insider information: an application of rational-expectations models,' The Journal of Political Economy, 90(4), 663-698.

Ponta, L., M. Raberto, A. Teglio and S. Cincotti (2018), 'An agent-based stock-flow consistent model of the sustainable transition in the energy sector,' Ecological Economics, 145 (C), 274-300.

Pozsar, Z., T. Adrian, A. B. Ashcraft and H. Boesky (2010), 'Shadow banking,' Staff Reports 458, Federal Reserve Bank of New York: New York, NY.

Raberto, M., B. Ozel, L. Ponta, A. Teglio and S. Cincotti (2018), 'From financial instability to green finance: the role of banking and credit market regulation in the Eurace model,' Journal of Evolutionary Economics, 1-37. Doi: 10.1007/s00191-018-0568-2. 
Raberto, M., A. Teglio and S. Cincotti (2008), Prospect Theory Behavioral Assumptions in an Artificial Financial Economy. Vol. 614 of Lecture Notes in Economics and Mathematical Systems. Springer: Berlin/Heidelberg, pp. 55-66.

Raberto, M., A. Teglio and S. Cincotti (2012), 'Debt deleveraging and business cycles. an agent-based perspective,' The Open-Access, Open-Assessment E-Journal, 6(2012-27), 1.

Riccetti, L., A. Russo and M. Gallegati (2015), 'An agent based decentralized matching macroeconomic model,' Journal of Economic Interaction and Coordination, 10(2), 305-332.

Russo, A., L. Riccetti and M. Gallegati (2016), 'Increasing inequality, consumer credit and financial fragility in an agent based macroeconomic model,' Journal of Evolutionary Economics, 26(1), 25-47.

Saunders, A. and L. Allen (2010), Credit Risk Management in and out of the Financial Crisis: new approaches to value at risk and other Paradigms. John Wiley \& Sons: New Jersey.

Segoviano, M., B. Jones, P. Lindner and J. Blankenheim (2013), 'Securitization; lessons learned and the road ahead,' IMF Working Papers 13/255, Vol. 13(255), 1, International Monetary Fund.

Singh, M. Aug (2013), ‘Collateral and monetary policy,' IMF Working Papers 13/186, Vol. 13(186), 1, International Monetary Fund.

Taylor, J. B. (1993), 'Discretion versus policy rules in practice,' Carnegie-Rochester Conference Series on Public Policy, 39, $195-214$.

Teglio, A., A. Mazzocchetti, L. Ponta, M. Raberto and S. Cincotti (2017), 'Budgetary rigour with stimulus in lean times: policy advices from an agent-based model,' Journal of Economic Behavior and Organization, in press.

Teglio, A., M. Raberto and S. Cincotti (2009), Explaining Equity excess return by Means of an Agent-Based Financial Market. Vol. 631 of Lecture Notes in Economics and Mathematical Systems. Springer, Ch. 12, pp. 145-156.

Teglio, A., M. Raberto and S. Cincotti (2010), Balance sheet approach to agent-based computational economics: the Eurace project. In: Combining Soft Computing and Statistical Methods in Data Analysis. Vol. 77 of Advances in Intelligent and Soft Computing. Springer Berlin/Heidelberg, pp. 603-610.

Tversky, A. and D. Kahneman (1992), 'Advances in prospect theory: cumulative representation of uncertainty,' Journal of Risk and Uncertainty, 5(4), 297-323.

Uribe, M. and S. Schmitt-Grohe (2017), Open Economy Macroeconomics. Princeton University Press: Princeton, New Jersey.

Wagner, W. (2007), 'The liquidity of bank assets and banking stability,' Journal of Banking and Finance, 31(1), $121-139$.

Watson, M. and J. Stock (1999), Business Cycle Fluctuations in U.S. Macroeconomic Time Series. Elsevier: Amsterdam, pp. 3-64.

Yeh, A., J. Twaddle and M. Frith (2005), Basel II: a new capital framework. Technical report, Bulletin, vol. 68, no. 3, Reserve Bank of New Zealand. 